\title{
Antiinflammatory Therapies for Cystic Fibrosis: Past, Present, and Future
}

\begin{abstract}
William A. Prescott, Jr., Pharm.D., and Cary E. Johnson, Pharm.D.
Inflammation is a major component of the vicious cycle characterizing cystic fibrosis pulmonary disease. If untreated, this inflammatory process irreversibly damages the airways, leading to bronchiectasis and ultimately respiratory failure. Antiinflammatory drugs for cystic fibrosis lung disease appear to have beneficial effects on disease parameters. These agents include oral corticosteroids and ibuprofen, as well as azithromycin, which, in addition to its antimicrobial effects, also possesses antiinflammatory properties. Inhaled corticosteroids, colchicine, methotrexate, montelukast, pentoxifylline, nutritional supplements, and protease replacement have not had a significant impact on the disease. Therapy with oral corticosteroids, ibuprofen, and fish oil is limited by adverse effects. Azithromycin appears to be safe and effective, and is thus the most promising antiinflammatory therapy available for patients with cystic fibrosis. Pharmacologic therapy with antiinflammatory agents should be started early in the disease course, before extensive irreversible lung damage has occurred.
\end{abstract}

Key Words: cystic fibrosis, inflammation, antiinflammatory, corticosteroid, ibuprofen, macrolide, azithromycin, antioxidant, antiprotease, nutrition.

(Pharmacotherapy 2005;25(4):555-573)

\section{OUTLINE}

Characteristics of Pulmonary Inflammation in Cystic Fibrosis

Therapies with Proven Antiinflammatory Effects

Corticosteroids

Ibuprofen

Azithromycin

Additional Therapies with Possible Antiinflammatory

Effects

Colchicine

Dornase alfa

Methotrexate

Montelukast

Pentoxifylline

From the School of Pharmacy and Pharmaceutical Sciences, State University of New York at Buffalo, Buffalo, New York (Dr. Prescott); and the College of Pharmacy, University of Michigan, and the Department of Pharmacy Services, University of Michigan Health System, Ann Arbor, Michigan (Dr. Johnson).

Address reprint requests to William A. Prescott, Jr., Pharm.D., School of Pharmacy and Pharmaceutical Sciences, State University of New York at Buffalo, 229 Cooke Hall, Buffalo, NY 14260; e-mail: prescott@buffalo.edu.
Nutritional Supplements

$\beta$-Carotene

Essential Fatty Acids

Future Directions

Conclusion

Cystic fibrosis is the most common lethal, genetically inherited disorder among Caucasians. ${ }^{1}$ The clinical features of cystic fibrosis occur as a result of mutations in the cystic fibrosis transmembrane conductance regulator gene. ${ }^{2}$ Consequently, the cystic fibrosis airway is exposed to a vicious cycle of obstruction, infection, and inflammation, all intimately linked. ${ }^{3}$ Airway inflammation begins early in the disease course, with notable neutrophil infiltration present in infants as young as 4 weeks. ${ }^{4-11}$ The inflammatory process persists throughout the patient's life and, if left unchecked, irreversibly damages the airways, leading to bronchiectasis and progressive decline in lung function. ${ }^{10}$ Pulmonary disease accounts for most of the morbidity and mortality in patients with cystic fibrosis. Therefore, 
interrupting this cycle with antiinflammatory agents may slow disease progression, improve quality of life, and delay respiratory failure. ${ }^{12}$ However, less than $50 \%$ of pulmonary practitioners prescribe specific antiinflammatory agents, and only $25 \%$ of patients with cystic fibrosis receive such therapy. ${ }^{13}$

The safety and efficacy of numerous antiinflammatory therapies have been studied for treatment of cystic fibrosis. Several agents have proved beneficial, particularly in younger patients with mild disease. However, safety concerns have limited the utility of certain drugs.

\section{Characteristics of Pulmonary Inflammation in Cystic Fibrosis}

Inflammation plays a pivotal role in the progression of lung destruction in patients with cystic fibrosis. The cystic fibrosis airway is characterized by persistent infiltration of vast numbers of neutrophils which, when present in excess, produce more harm than good (Figure
1). 1, 3, 4, 6, 8, 9, 11, 14-24 Bacterial infection and continuing colonization are the primary stimuli for inflammation in the cystic fibrosis airway. ${ }^{1}$ However, pulmonary inflammation has been observed in young children without identifiable infection. ${ }^{4,6,8,11}$ If these children were truly without infection, one might speculate that the lack of functional cystic fibrosis transmembrane conductance regulator in the epithelial lining of the cystic fibrosis lung may contribute to the inflammatory process. ${ }^{23}$ Regardless of whether infection precedes or supersedes inflammation, the two become closely integrated in cystic fibrosis lung disease. ${ }^{24}$

\section{Therapies with Proven Antiinflammatory Effects}

\section{Corticosteroids}

The therapeutic efficacy and safety of several oral and inhaled corticosteroids have been evaluated in children with cystic fibrosis, but the

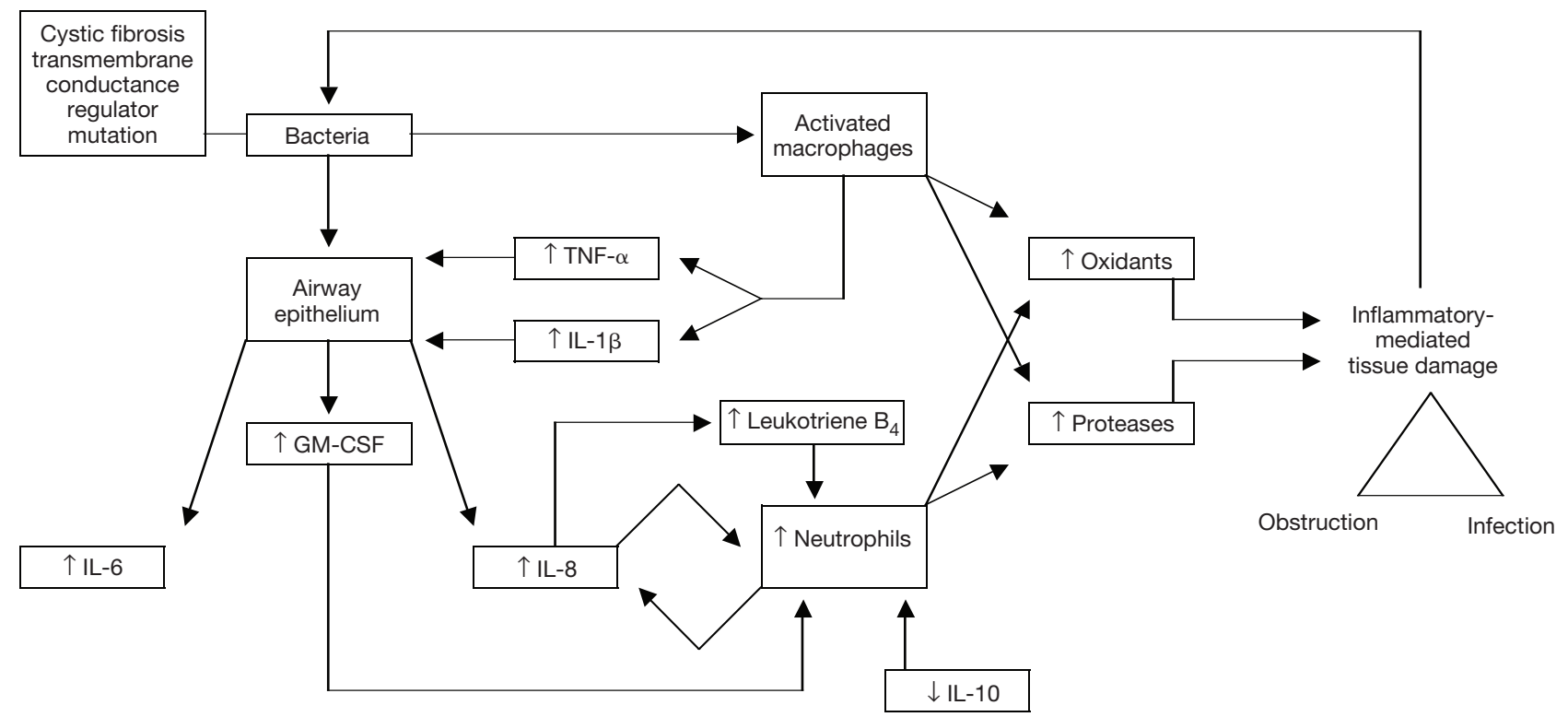

Figure 1. Pathophysiology of cystic fibrosis airway inflammation and potential targets of antiinflammatory therapy. The inflammatory process is initiated through interaction of the epithelium with bacteria or bacterial products. Then interleukin (IL)-8, IL-6, and possibly granulocyte-macrophage colony-stimulating factor (GM-CSF) are produced directly and indirectly through stimulated macrophage production of IL-1 $\beta$ and tumor necrosis factor (TNF) $\alpha$. The latter two inflammatory mediators stimulate the epithelium to produce IL-8, IL-6, and GM-CSF in excess. In addition, concentration of the antiinflammatory cytokine IL-10 is reduced in the cystic fibrosis airway, eliminating the inhibitory effect on production of IL-8 and TNF- $\alpha$. The IL- 8 recruits neutrophils into the airway, which subsequently release neutrophil elastase and additional IL- 8 and leukotriene $\mathrm{B}_{4}$, leading to further neutrophil influx. Neutrophils release large amounts of oxidants and proteases, which subsequently overwhelm the deficient antioxidant and dysfunctional antiprotease defenses of the cystic fibrosis airway, leading to direct tissue damage. In addition, neutrophil elastase, a major protease in the cystic fibrosis lung, may indirectly cause harm to the epithelium by increasing airway obstruction, contributing to the persistence of infection and promoting the generation of chemoattractants. (From references 1, 3, 4, 6, 8, 9, 11, 14-24.) 
precise mechanism through which these agents control inflammation and affect cystic fibrosis pulmonary disease has not been elucidated. Investigators have proposed that the antiinflammatory actions of corticosteroids in cystic fibrosis are mediated through inhibition of interleukin (IL)- $1 \alpha$ and IL-2 receptor expression. ${ }^{25}$ Serum immunoglobulin $\mathrm{G}$ ( $\operatorname{Ig} G)$ concentrations are also significantly decreased with systemic corticosteroid therapy. This effect may reduce immune complex formation and complement activation, thereby diminishing lung damage.

\section{Oral}

Prednisone and prednisolone are oral glucocorticoids with potent antiinflammatory effects. Prednisone has effectively controlled the inflammation of cystic fibrosis pulmonary disease; however, safety concerns limit its use for longterm treatment in children with the disease. ${ }^{25-28}$

The benefits of oral prednisone on morbidity and progression of lung disease in children with cystic fibrosis was first reported in a 4-year prospective, randomized, double-blind, placebocontrolled trial of 45 patients aged $1-12$ years with mild-to-moderate cystic fibrosis lung disease. ${ }^{26}$ Of these patients, 24 (mean age 6.3 yrs) were randomly allocated to placebo, and 21 (mean age 6.7 yrs) to treatment with prednisone $2 \mathrm{mg} / \mathrm{kg}$, maximum $60 \mathrm{mg}$, every other day.

After 4 years, the prednisone-treated group exhibited significantly higher values than the placebo group with respect to vital capacity $(\mathrm{p}<0.01)$, peak expiratory flow rate $(\mathrm{p}<0.005)$, and forced expiratory volume in 1 second $\left(\mathrm{FEV}_{1}\right)$ $(\mathrm{p}<0.005)$. In the prednisone group, five $(24 \%)$ patients required nine hospital admissions for cystic fibrosis-related pulmonary disease; in the placebo group, 10 (42\%) patients required 35 admissions $(\mathrm{p}<0.001)$. Gains in height $(\mathrm{p}<0.025)$ and weight $(\mathrm{p}<0.005)$ were significantly better in the treatment versus placebo group at the conclusion of the study.

To confirm the outcomes reported in the first trial, a second, larger, prospective, double-blind, placebo-controlled study was conducted. ${ }^{27} \mathrm{~A}$ total of 285 patients aged 6-14 years (mean 9.5 yrs) with clinically stable cystic fibrosis and a ratio of $\mathrm{FEV}_{1}$ :forced vital capacity (FVC) greater than $60 \%$ were equally stratified in a randomized manner to either placebo or alternate-day prednisone $1 \mathrm{mg} / \mathrm{kg}$ (low dose) or $2 \mathrm{mg} / \mathrm{kg}$ (high dose, maximum $60 \mathrm{mg}$ ). The study was discontinued prematurely in the high- and lowdose groups after 2 and 3 years, respectively, secondary to unacceptable adverse effects.

Predicted FVC was greater in patients receiving prednisone $1 \mathrm{mg} / \mathrm{kg}(\mathrm{p}<0.0001)$ or $2 \mathrm{mg} / \mathrm{kg}$ $(\mathrm{p}<0.01)$ than in those receiving placebo. No significant difference in effect was observed between the two prednisone-treated groups ( $\mathrm{p}>0.21)$. In the $1-\mathrm{mg} / \mathrm{kg}$ group, improvement in FVC was first noted at 6 months, plateaued thereafter, and was sustained for the rest of the study period $(p<0.0025)$. Mean predicted $F E V_{1}$ declined to a significantly lesser extent in the 1$\mathrm{mg} / \mathrm{kg}$ group than in the placebo group $(\mathrm{p}<0.02)$. Hospitalization rates and length of stay, Shwachman score, Brasfield score, and peak expiratory flow rate were not significantly different between the prednisone and placebo groups.

In a follow-up study assessing the long-term effects of prednisone, the improvement in pulmonary function observed in patients treated with alternate-day prednisone $1 \mathrm{mg} / \mathrm{kg}$ was no longer present 6-7 years after therapy was discontinued. ${ }^{29}$ In fact, the $13.5 \%$ decline in $\mathrm{FEV}_{1}$ in the low-dose prednisone group during the follow-up period was 3 times greater than the $4.5 \%$ decline in the placebo patients. The weight of the prednisone-treated children declined to baseline weight within 1-2 years after treatment discontinuation.

Although effective, the utility of corticosteroids in the treatment of cystic fibrosis pulmonary disease is limited by long-term safety concerns..$^{27,28}$ An early study suggested that therapy with oral prednisone in children with cystic fibrosis would not produce significant adverse effects. ${ }^{26}$ However, better-powered studies concluded that long-term treatment with corticosteroids was associated with significant risks. ${ }^{27,} 28$ Glucose intolerance, cataract formation, multiple bone fractures secondary to osteoporosis or osteopenia, cushingoid effects, and anorexia nervosa occurred in a dose-dependent fashion. ${ }^{27,28,30}$ The percentage of patients colonized with Pseudomonas aeruginosa increased from baseline when prednisone $1 \mathrm{mg} / \mathrm{kg}(\mathrm{p}<0.01)$ and $2 \mathrm{mg} / \mathrm{kg}(\mathrm{p}<0.05)$ every other day were given. ${ }^{27}$ Prednisone 2 $\mathrm{mg} / \mathrm{kg}$ every other day for more than 6 months or $1 \mathrm{mg} / \mathrm{kg}$ every other day for more than 24 months was associated with substantial negative effects on growth. ${ }^{27-29}$

Catch-up growth occurs in most children, both boys and girls, 2-3 years after discontinuation of prednisone therapy. ${ }^{29}$ However, growth impairment among prepubertal boys, most prominently those aged $6-8$ years, persists for 10 years after 
Table 1. Studies of Inhaled Corticosteroid Therapy in Patients with Cystic Fibrosis

\begin{tabular}{|c|c|c|c|c|c|c|}
\hline Study Design & $\begin{array}{c}\text { No. of } \\
\text { Patients }\end{array}$ & $\begin{array}{l}\text { Age Range, } \\
\text { Mean, Median } \\
\quad(\text { yrs })\end{array}$ & $\begin{array}{l}\text { Drug and Dosage } \\
\qquad(\mu \mathrm{g} / \text { day })\end{array}$ & $\begin{array}{l}\text { Treatment } \\
\text { Duration } \\
\text { (wks) }\end{array}$ & $\begin{array}{l}\text { Sputum Inflammatory } \\
\text { Marker Improvement } \\
\text { from Baseline }\end{array}$ & $\begin{array}{l}\text { Change in } \\
\mathrm{FEV}_{1} \text { and FVC } \\
\text { vs Placebo }\end{array}$ \\
\hline $\mathrm{R}, \mathrm{DB}, \mathrm{PC}^{34}$ & 13 & $\begin{array}{l}\text { 4-29, } \\
\text { NR, } 14\end{array}$ & Beclomethasone 400 & 16 & $\mathrm{NS}^{\mathrm{a}}$ & FVC: $\mathrm{NS}^{\mathrm{a}}$ \\
\hline $\mathrm{R}, \mathrm{DB}, \mathrm{CO}, \mathrm{PC}^{35}$ & 12 & $\begin{array}{l}16-45 \\
27, \mathrm{NR}\end{array}$ & Budesonide 1600 & 6 & NA & $\begin{array}{l}\mathrm{FEV}_{1}: \mathrm{NS}^{\mathrm{a}} \\
\text { FVC: } \mathrm{NS}^{\mathrm{a}}\end{array}$ \\
\hline $\mathrm{R}, \mathrm{PC}^{36}$ & 25 & $\begin{array}{l}\text { 6-28, } \\
\text { 20, NR }\end{array}$ & Beclomethasone 1500 & 4 & NA & $\begin{array}{l}\mathrm{FEV}_{1}: \mathrm{NS}^{\mathrm{a}} \\
\text { FVC: NS }\end{array}$ \\
\hline $\mathrm{R}, \mathrm{DB}, \mathrm{PC}^{37}$ & 30 & $\begin{array}{l}\text { NR, } \\
20, \mathrm{NR}\end{array}$ & Budesonide 1600 & $9-20$ & $\mathrm{NS}^{\mathrm{a}}$ & $\begin{array}{l}\mathrm{FEV}_{1}: \mathrm{NS}^{\mathrm{a}} \\
\text { FVC: } \mathrm{NS}^{\mathrm{a}}\end{array}$ \\
\hline $\mathrm{R}, \mathrm{DB}, \mathrm{CO}, \mathrm{PC}^{38}$ & 23 & $\begin{array}{l}7-17, \\
10, \mathrm{NR}\end{array}$ & Fluticasone 400 & 6 & $\mathrm{NS}^{\mathrm{a}}$ & $\begin{array}{l}\mathrm{FEV}_{1}: \mathrm{NS}^{\mathrm{a}} \\
\text { FVC: } \mathrm{NS}^{\mathrm{a}}\end{array}$ \\
\hline $\mathrm{R}, \mathrm{OL}, \mathrm{PC}^{39}$ & 12 & $\begin{array}{l}\text { 16-38, } \\
\text { NR, } 26\end{array}$ & Fluticasone 1000 & 3 & $N S^{c}$ & $\begin{array}{l}\text { FEV }_{1}: \mathrm{NS}^{\mathrm{b}} \\
\text { FVC: } \mathrm{NS}^{\mathrm{c}}\end{array}$ \\
\hline
\end{tabular}

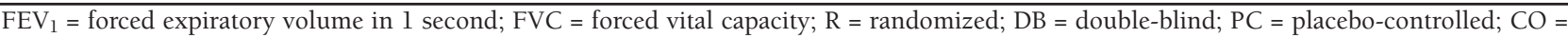
crossover; $\mathrm{OL}=$ open-label; $\mathrm{NR}=$ not reported; $\mathrm{NA}=$ safety data not assessed; NS = not significant.

No significant differences were observed in adverse drug reactions for study drug compared with placebo in all studies except reference 36, in which adverse events were not assessed.

${ }^{\mathrm{a}} \mathrm{p}>0.05$

${ }^{\mathrm{b}} \mathrm{p}>0.1$.

$\mathrm{c}>0.2$.

treatment with prolonged alternate-day prednisone. The final predicted height in this patient subgroup is significantly reduced $(\mathrm{p}=0.02)$. The risk of corticosteroid-induced adverse effects is greater during concomitant therapy with itraconazole and corticosteroids since itraconazole is a potent inhibitor of corticosteroid metabolism. ${ }^{31}$, 32 When corticosteroids and itraconazole are administered concomitantly to treat allergic bronchopulmonary aspergillosis, monitoring patients for symptoms suggestive of drug-related adverse events is indicated.

In children with cystic fibrosis, treatment with prednisone improves pulmonary function. ${ }^{26,27}$ However, given the short-lived benefits and serious adverse effects, prolonged prednisone therapy for suppression of inflammation cannot be recommended for children with cystic fibrosis. ${ }^{27-32}$ When indicated, prednisone should be administered in the lowest effective dose for a limited time.

\section{Inhaled}

Inhaled corticosteroids are better tolerated and produce fewer adverse effects than systemically administered dosage forms. ${ }^{33}$ Of the five available inhalation corticosteroids, beclomethasone, budesonide, and fluticasone have been evaluated in children with cystic fibrosis. ${ }^{34-39}$

Although one uncontrolled study suggested that inhaled corticosteroids might modulate neutrophil influx into the cystic fibrosis airway, mitigation of pulmonary inflammation has not been observed in placebo-controlled trials. ${ }^{34,37-40}$ Inhaled corticosteroids may attenuate bronchial hyperresponsiveness in patients with cystic fibrosis and may improve cough and dyspnea. ${ }^{35,37}$ However, in six controlled studies involving a total of 191 patients aged 4 years or older, no clinically or statistically significant benefit in $\mathrm{FEV}_{1}$ or FVC was observed (Table 1). ${ }^{34-39}$

In clinical trials involving children and adults with cystic fibrosis, treatment with inhaled corticosteroids was well tolerated for up to 20 weeks. ${ }^{34,35,37-39}$ Whereas an apparent increase in P. aeruginosa colonization in patients with cystic fibrosis was observed incidentally in one small study, ${ }^{35}$ no significant difference was reported in two separate controlled trials. ${ }^{40,41}$ Whereas longterm studies assessing the effect of inhaled corticosteroids on growth are lacking for children with cystic fibrosis, final predicted height and bone mineral density are generally attained in this pediatric population. ${ }^{33,42}$

Adrenocorticotropic hormone suppression tests in patients with cystic fibrosis have indicated little or no systemic effect of inhaled corticosteroids on the adrenal axis. ${ }^{37,} 40$ However, Cushing's syndrome and complete suppression of endogenous glucocorticoid secretion have occurred with administration of inhaled 
budesonide combined with itraconazole. ${ }^{43,44}$ This effect is attributed to inhibition of budesonide metabolism by itraconazole by the cytochrome P450 3A enzyme system. Routine monitoring for adrenal insufficiency is indicated when inhaled corticosteroids and itraconazole are concomitantly administered.

Delivery of aerosolized agents to the lungs, which averages $10-40 \%$ of total drug delivered, is dependent on the severity of lung disease and the specific delivery device and technique used. ${ }^{33,42}$ In patients with cystic fibrosis, the fraction of the dose ultimately reaching the site of the most severe inflammation may be poor given the viscous, mucus-lined epithelium through which it must pass. In children, the drug may never reach its primary site of action, which may account for the lack of efficacy demonstrated by inhaled corticosteroids in controlled clinical trials.

In theory, inhaled corticosteroids are a novel approach-administering a potent antiinflammatory agent directly to the disease site-to treating pulmonary inflammation in patients with cystic fibrosis. Although potentially safe, studies have failed to demonstrate any benefit after treatment with these drugs in children with cystic fibrosis. Thus, evidence-based medicine suggests that further studies are necessary before routine treatment with inhaled corticosteroids can be recommended.

\section{Ibuprofen}

Ibuprofen is an oral nonsteroidal antiinflammatory drug commonly used in children to treat acute pain and fever. ${ }^{45}$ The recommended antipyretic and analgesic dosage is $5-10 \mathrm{mg} / \mathrm{kg} \mathrm{3-4}$ times/day. In one study, ibuprofen $20-30 \mathrm{mg} / \mathrm{kg}$ twice/day had beneficial effects on both pulmonary function and nutrition in children with cystic fibrosis. ${ }^{46}$ Based on these results, the Cystic Fibrosis Foundation has advocated ibuprofen as an antiinflammatory agent for treating patients aged 5 years or older with cystic fibrosis whose predicted $\mathrm{FEV}_{1}$ is $60 \%$ or greater. ${ }^{47}$ Despite reported benefits in children aged 5-13 years, less than $10 \%$ of patients with cystic fibrosis in the United States are treated with highdose ibuprofen. ${ }^{13}$ The percentage of children receiving ibuprofen may be low due to the need for therapeutic drug monitoring and concerns regarding the clinical safety and tolerability of this agent.

Ibuprofen is an inhibitor of cyclooxygenase and, at high doses, lipoxygenase. Through inhibition of the lipoxygenase pathway, leukotriene $\mathrm{B}_{4}$ production is mitigated, and neutrophil migration and function are impaired. ${ }^{48-59}$ The antiinflammatory effects of ibuprofen in patients with cystic fibrosis occur when peak plasma concentration exceeds $50 \mu \mathrm{g} / \mathrm{ml} .{ }^{59}$ Concentrations below this threshold result in a paradoxical increase in inflammation. ${ }^{56-60}$ This proinflammatory effect is believed to occur as a result of substrate shunting from the cyclooxygenase to the lipoxygenase pathway. ${ }^{59}$ Therefore, with plasma concentrations less than $50 \mu \mathrm{g} / \mathrm{ml}$, ibuprofen may hasten cystic fibrosis lung deterioration.

In children with cystic fibrosis, ibuprofen peak plasma concentration and area under the concentration-time curve are decreased; however, the apparent volume of distribution and clearance are significantly increased. ${ }^{61}$ As the pharmacokinetics of ibuprofen are dependent on the dose and dosage form used and on the patient's body weight and fasted or fed state, significant variability occurs among individual patients with cystic fibrosis. ${ }^{61-63}$ In view of ibuprofen's narrow therapeutic window, and the significant interpatient pharmacokinetic variability, therapeutic drug concentration monitoring is necessary. ${ }^{46}$

Ibuprofen is most commonly given in tablet form. Children often cannot swallow tablets; thus, suspension and chewable tablet formulations are attractive alternatives. The suspension form is absorbed most rapidly. ${ }^{64-66}$ Plasma concentrations should be obtained at 30, 45, and 60 minutes after administration of a dose. ${ }^{65,66}$ Time to the peak plasma concentration is longer with ibuprofen tablets than with the liquid formulation. Thus, plasma concentrations should be checked at 1, 2, and 3 hours after administration with the tablet form. ${ }^{61,64-66}$ Given the limited available data, no definitive dosing recommendations or blood sampling guidelines can be provided for ibuprofen chewable tablets. ${ }^{65}$ To optimize therapy regardless of the form of ibuprofen administered, peak plasma concentration must be accurately determined to prevent misguided dosage adjustments.

In a randomized, double-blind, placebocontrolled trial, high-dose ibuprofen had clinically beneficial effects on $\mathrm{FEV}_{1}$ and ideal body weight (IBW). ${ }^{46}$ The study involved 85 patients, aged 5-39 years, with cystic fibrosis. Patients were excluded if they had received systemic corticosteroids, inhaled corticosteroids, or nonsteroidal antiinflammatory drugs for more than 2 weeks within 2 years of recruitment or 
inhaled cromolyn in the 6 months preceding the study. Of the 85 patients, 43 were randomly assigned to placebo, 42 to ibuprofen tablets. Food and pancreatic enzymes were withheld for 2 hours after each dose. Ibuprofen $20-30 \mathrm{mg} / \mathrm{kg}$ twice/day was the starting dosage. This was adjusted using pharmacokinetic analysis, with a goal peak plasma concentration of $50-100 \mu \mathrm{g} / \mathrm{ml}$.

Ibuprofen $20-30 \mathrm{mg} / \mathrm{kg}$ produced a peak plasma ibuprofen concentration of $50-100 \mu \mathrm{g} / \mathrm{ml}$ in most patients. The dose range at which all patients attained therapeutic concentrations was $16-32 \mathrm{mg} / \mathrm{kg}$. The dose was adjusted based on pharmacokinetic analysis every 3 years, or sooner if body weight increased $25 \%$. The primary outcome measure, $\mathrm{FEV}_{1}$, declined 59\% more slowly in patients treated with ibuprofen than in those assigned to placebo in the completedtreatment analysis $(p=0.03)$. This benefit was observed only in patients who were younger than 13 years at the start of treatment. In this subgroup, the rate of decline in $\mathrm{FEV}_{1}$ was reduced by $65 \%(\mathrm{p}=0.01)$ and $88 \%(\mathrm{p}=0.005)$ in the intent-to-treat and completed-treatment analysis, respectively. The FVC and forced expiratory flow at $25-75 \%$ of FVC (FEF $25-75)$ also deteriorated, to a lesser extent, in ibuprofentreated patients at study completion $(\mathrm{p}<0.05)$.

Patients in the ibuprofen group maintained their percent IBW throughout the 4-year study period $(\mathrm{p}=0.01)$. Compliance as assessed by tablet count and blood monitoring was approximately $70 \%$ in each group. Although ibuprofen effectively improved $\mathrm{FEV}_{1}$ and percent IBW, the results of this study must be interpreted with caution. The effect of ibuprofen on IBW was most pronounced in the younger patients (5-13 yrs), and the improved $\mathrm{FEV}_{1}$ was observed only in this group. Since the information representing these younger patients was a post hoc analysis involving only 36 patients, further studies are needed to determine the clinical importance of these findings in this age group.

In healthy children, intermittent ibuprofen in recommended dosages is associated with minimal risk for gastrointestinal bleeding and nephrotoxicity. ${ }^{67}$ Since higher ibuprofen dosages have increased the risk for gastrointestinal adverse effects, one might expect high-dose ibuprofen to be poorly tolerated by patients with cystic fibrosis. ${ }^{68}$ Neither a randomized, double-blind, placebo-controlled trial of 85 patients nor a retrospective review of 1354 patients prescribed an initial dosage of ibuprofen $20-30 \mathrm{mg} / \mathrm{kg}$ twice/day reported a significant increase in the risk of gastrointestinal toxicity in children with cystic fibrosis. ${ }^{46,69}$ However, safety data from the randomized trial were derived from a small patient pool, with only 17 patients aged 5-13 years, the age group in which ibuprofen has had the most pronounced benefit. ${ }^{46}$ Indeed, anecdotal evidence and clinical experience with high-dose ibuprofen suggest that this regimen is not without gastrointestinal adverse effects. ${ }^{70}$

Risk of renal toxicity is a second concern associated with ibuprofen therapy. Studies have not evaluated the effects of high-dose ibuprofen on renal function in patients with cystic fibrosis. However, an increased risk for renal toxicity has been reported when this agent is used with intravenous aminoglycosides. ${ }^{71,72}$ Ibuprofen administration can be interrupted during aminoglycoside therapy without producing a rebound increase in pulmonary inflammation, and this practice is recommended. ${ }^{60}$ Data concerning safety and efficacy after long-term therapy with high-dose ibuprofen are lacking.

Based on the studies described, ibuprofen therapy improves maintenance of percent IBW and slows the decline of lung function when treatment is begun in children with cystic fibrosis, aged 5-13 years, who have a predicted $\mathrm{FEV}_{1}$ of $60 \%$ or greater. ${ }^{46}$ Although data directly assessing the effect of ibuprofen on long-term survival in patients with cystic fibrosis are lacking, $\mathrm{FEV}_{1}$ and percent IBW are predictors of mortality. ${ }^{73}$ The recommended initial dosage is ibuprofen $20-30 \mathrm{mg} / \mathrm{kg}$ twice/day, titrated as needed to a dosage that produces a peak plasma concentration of $50-100 \mu \mathrm{g} / \mathrm{ml}$ based on pharmacokinetic monitoring.

Patients or caregivers should be instructed to separate the administration time of ibuprofen and pancreatic enzymes by at least 2 hours and to administer the ibuprofen on an empty stomach, if tolerated, to allow optimal absorption. ${ }^{46}$ To ensure that therapeutic concentrations are maintained with prolonged treatment, pharmacokinetic analysis should be performed every 3 years or with body weight increases of $25 \%$ or more. The need for periodic pharmacotherapeutic monitoring and the lack of adequate safety data in patients aged 5-13 years when treated with high-dose ibuprofen have limited the routine therapeutic use of this agent in children with cystic fibrosis.

Cyclooxygenase-2 inhibitors, such as celecoxib, rofecoxib, and valdecoxib, are often better tolerated than ibuprofen. ${ }^{74-76}$ However, the antiinflammatory mechanism of ibuprofen in 
cystic fibrosis differs from cyclooxygenase inhibition. ${ }^{48-59}$ Treatment with cyclooxygenase- 2 inhibitors in healthy children or in children with cystic fibrosis has not been evaluated.

\section{Azithromycin}

Azithromycin is a macrolide commonly used for its antibacterial activity in both children and adults. It is approved for treatment of acute otitis media and community-acquired pneumonia in patients older than 6 months and for treatment of pharyngitis or tonsillitis in those aged 2 years or older. ${ }^{77}$ Azithromycin has a long tissue half-life and accumulates in the sputum and lungs of treated patients. ${ }^{78}$ The potential role of azithromycin in cystic fibrosis is extrapolated from experience with diffuse panbronchiolitis, a respiratory disease similar to cystic fibrosis. In patients with diffuse panbronchiolitis, long-term erythromycin therapy improved both symptoms and survival. ${ }^{79,80}$

Azithromycin has been evaluated as a treatment option for patients with cystic fibrosis for its antiinflammatory properties. ${ }^{81}$ The precise mechanism through which azithromycin exerts these effects has not been elucidated (Figure 2). ${ }^{82-99}$ Antimicrobial classes typically used in the treatment of acute cystic fibrosis exacerbations, such as third-generation cephalosporins, aminoglycosides, and fluoroquinolones, do not appear to exert any significant direct antiinflammatory action and have not been included in this review. ${ }^{100}$

Treatment with either erythromycin or clarithromycin has not been beneficial in cystic fibrosis. ${ }^{101}$ Six trials have evaluated the effects of azithromycin in children and adults with cystic fibrosis (Table 2). ${ }^{102-107}$ Of the three randomized, placebo-controlled trials conducted, two involved patients younger than 18 years. ${ }^{106,107}$ Although a benefit with azithromycin was observed in both of these studies, the more recent one provides the most compelling evidence of therapeutic improvement. ${ }^{107}$

In a randomized, double-blind, placebo-

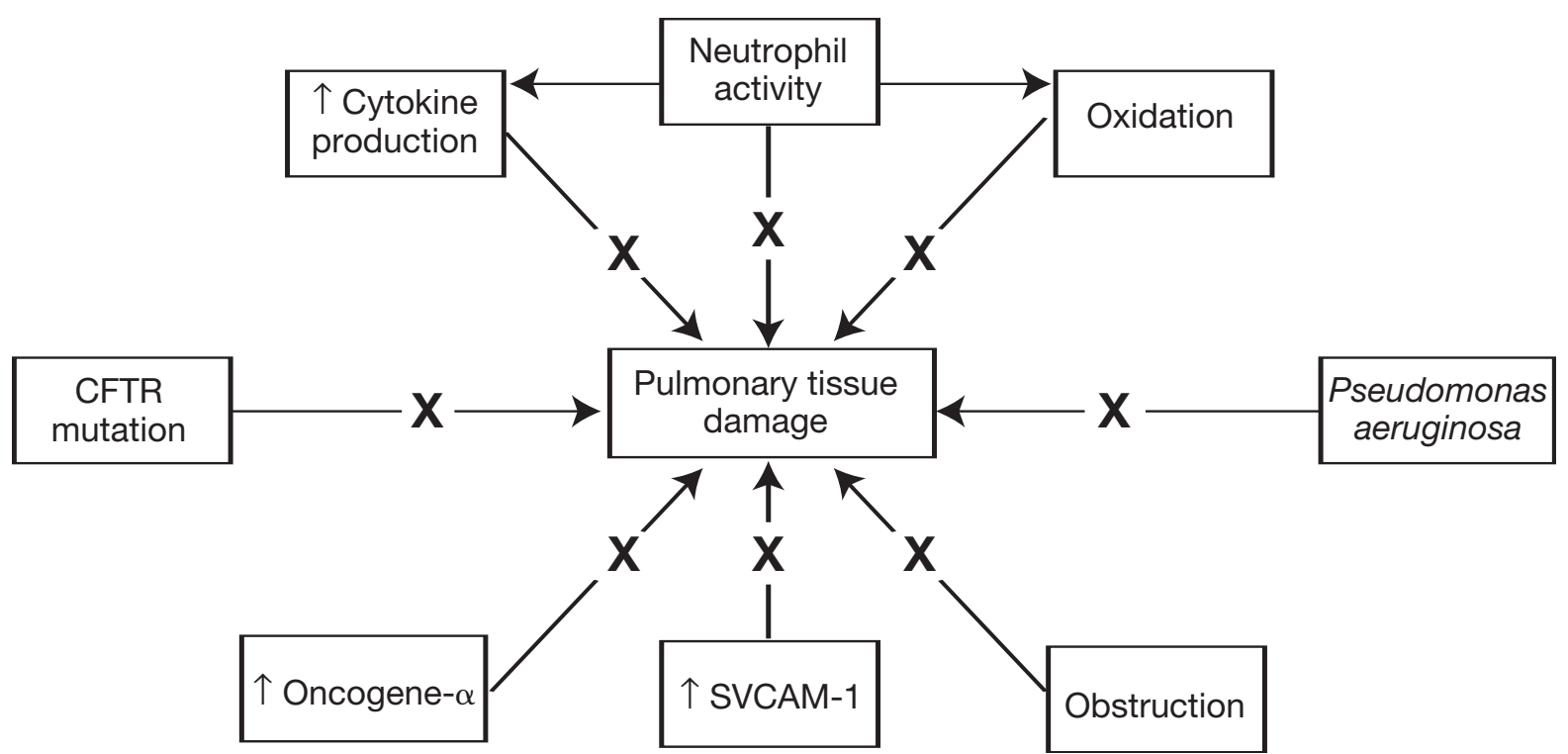

Figure 2. Proposed antiinflammatory mechanisms of macrolide antibiotics. The precise mechanism by which azithromycin mitigates inflammation is unknown, but it affects neutrophils through mediation of apoptosis, migration, chemotactic activity, and phagocytic function. Azithromycin is an indirect antioxidant and may prevent lung damage through this function. Therapy with this agent has inhibited production of nitric oxide, prostaglandin $\mathrm{E}_{2}$, and proinflammatory cytokines interleukin (IL)-8, IL-1 $\alpha$, and tumor necrosis factor (TNF)- $\alpha$. Azithromycin may also downregulate growth-related oncogene- $\alpha$ as well as soluble vascular cell adhesion molecule (SVCAM)-1. Reduced sputum viscoelasticity and improved mucociliary and cough transportability of airway secretions has been noted. Antagonism of the virulence of Pseudomonas aeruginosa has been proposed as a mechanism, an effect mediated through a decrease in airway adherence, inhibition of production of various exoproducts, and interference with Pseudomonas mucoid-alginate biofilm formation. In addition, it may affect Pseudomonas aeruginosa's viability directly despite subinhibitory minimum inhibitory concentrations. Restoration of the cystic fibrosis transmembrane conductance regulator (CFTR) chloride channel is an additional possible mechanism. X = mitigation of adverse effect. (From references 82-99.) 
Table 2. Studies of Azithromycin Therapy in Patients with Cystic Fibrosis

\begin{tabular}{|c|c|c|c|c|c|c|}
\hline Study Design & $\begin{array}{c}\text { No. of } \\
\text { Patients }\end{array}$ & $\begin{array}{c}\text { Age Range, } \\
\text { Mean, Median } \\
\text { (yrs) }\end{array}$ & Azithromycin Dosage & $\begin{array}{l}\text { Treatment } \\
\text { Duration } \\
(\mathrm{mo})\end{array}$ & $\begin{array}{l}\text { Change in } \mathrm{FEV}_{1} \\
\mathrm{FVC}, \mathrm{FEF}_{25-75} \\
\text { (\% increase) }\end{array}$ & $\begin{array}{c}\text { Adverse } \\
\text { Drug } \\
\text { Reactions } \\
\end{array}$ \\
\hline $\mathrm{OL}^{102}$ & 7 & $\begin{array}{l}\text { 6-17, } \\
12, \mathrm{NR}\end{array}$ & NR & Median 7.2 & $\begin{array}{l}F_{E V}: 11.0^{\mathrm{a}} \\
\text { FVC: } 11.3^{\mathrm{a}}\end{array}$ & NS \\
\hline $\mathrm{M}, \mathrm{PC}^{103}$ & 36 & $\begin{array}{l}\text { NR, } \\
\text { NR, NR }\end{array}$ & 250 mg q.d. & Mean 9.4 & $\begin{array}{l}F_{E V}: 2.2^{b} \\
\text { FVC: } 5.7^{c}\end{array}$ & NS \\
\hline Observational $^{104}$ & 14 & $\begin{array}{l}\text { NR, } \\
24, \mathrm{NR}\end{array}$ & 250 mg q.o.d. ${ }^{\mathrm{d}}$ & Mean 22.3 & $\begin{array}{l}F V_{1}: 5.8^{\mathrm{b}} \\
\text { FVC: } 4.8^{\mathrm{e}} \\
\text { FEF }_{25-75}: 6.5^{\mathrm{a}}\end{array}$ & NS \\
\hline $\mathrm{R}, \mathrm{DB}, \mathrm{PC}^{105}$ & 60 & $\begin{array}{l}18-44, \\
28, \mathrm{NR}\end{array}$ & 250 mg q.d. & 3 & $\begin{array}{l}\mathrm{FEV}_{1}: 3.0^{\mathrm{a}} \\
\text { FVC: } 3.8^{\mathrm{a}}\end{array}$ & \\
\hline $\mathrm{R}, \mathrm{DB}, \mathrm{PC}, \mathrm{CO}^{106}$ & 41 & $\begin{array}{l}\text { 8-18, } \\
\text { NR, } 14\end{array}$ & $\begin{array}{l}250 \mathrm{mg} \text { q.d. }(A B W \leq 40 \mathrm{~kg}) \\
500 \mathrm{mg} \text { q.d. }(A B W>40 \mathrm{~kg})\end{array}$ & 6 & $\begin{array}{l}F V_{1}: 5.4^{\mathrm{e}} \\
\text { FVC: } 3.9^{\mathrm{e}} \\
\text { FEF }_{25-75}: 11.4^{\mathrm{e}}\end{array}$ & NS \\
\hline $\mathrm{R}, \mathrm{DB}, \mathrm{PC}^{107}$ & 185 & $\begin{array}{l}\text { 6-Adult, } \\
\text { 20, NR }\end{array}$ & $\begin{array}{l}250 \mathrm{mg} \text { MWF }(A B W<40 \mathrm{~kg}) \\
500 \mathrm{mg} \text { MWF }(A B W \geq 40 \mathrm{~kg})\end{array}$ & 6 & $\begin{array}{l}\mathrm{FEV}_{1}: 4.4^{\mathrm{c}} \\
\text { FVC: } 3.7^{\mathrm{c}}\end{array}$ & $\begin{array}{l}\text { Nausea, } \\
\text { diarrhea, } \\
\text { wheezing }\end{array}$ \\
\hline
\end{tabular}

$\mathrm{FEV}_{1}=$ forced expiratory volume in 1 second $; \mathrm{FVC}=$ forced vital capacity; $\mathrm{FEF}_{25-75}=$ forced expiratory flow at $25-75 \%$ of $\mathrm{FVC}$; OL $=$ openlabel; $\mathrm{M}=$ matched; $\mathrm{PC}=$ placebo controlled; $\mathrm{CO}=$ crossover; $\mathrm{NR}=$ not reported; $\mathrm{NS}$ = no significant difference compared with placebo; $\mathrm{ABW}=$ actual body weight; MWF = Monday, Wednesday, and Friday

${ }^{\mathrm{a}} \mathrm{p}<0.05$ vs baseline.

${ }^{\mathrm{b}} \mathrm{p}=0.05$ vs placebo.

c $\mathrm{p}<0.01$ vs placebo.

${ }^{\mathrm{d}}$ Adjusted to $250 \mathrm{mg} /$ day in 8 of 14 patients.

${ }^{\mathrm{e}} \mathrm{p}>0.05$.

${ }_{\mathrm{p}}^{\mathrm{p}}<0.05$ vs placebo.

controlled study involving 60 adults with cystic fibrosis, treatment with azithromycin led to an improvement in total quality of life $(p=0.035)$, a reduction in antibiotic therapy associated with acute respiratory exacerbations $(\mathrm{p}<0.037)$, and a slowed rate of decline in predicted $F_{E V}$ $(\mathrm{p}=0.047)$ and FVC $(\mathrm{p}=0.001) .{ }^{105}$ This benefit was observed despite baseline patient characteristics indicating the treatment group had less lung function than the placebo group (mean $\mathrm{FEV}_{1}$ 50.9\% vs 62.3\%, mean FVC 67.3\% vs $77.5 \%)$. The treatment group also was shorter, on average, and weighed less than the placebo group. However, outcome changes in lung function were small, indicating maintenance rather than improvement.

In the first trial involving patients younger than 18 years with cystic fibrosis, pulmonary function was only modestly affected after a 6month course of azithromycin. ${ }^{106}$ This study-a 15-month, prospective, randomized, doubleblind, placebo-controlled, crossover trialincluded 41 children (18 boys, 23 girls) aged 8-18 years, with a median $\mathrm{FEV}_{1}$ of $61 \%$ (range $33-80 \%)$. A history of chronic P. aeruginosa colonization was not a specific entry criterion.
Exclusion criteria were liver disease, hearing impairment, Burkholderia cepacia colonization, previous organ transplantation, treatment with macrolide antibiotics or oral corticosteroids for more than 14 days, or treatment with dornase alfa begun within 2 months of enrollment.

Azithromycin dosage was based on weight; patients weighing $40 \mathrm{~kg}$ or less received $250 \mathrm{mg}$ once/day; those weighing more than $40 \mathrm{~kg}$ received $500 \mathrm{mg}$ once/day. A clinically significant change in the primary outcome measure, $\mathrm{FEV}_{1}$, and the secondary outcome measures, FVC and $\mathrm{FEF}_{25-75}$, was defined as a change of more or less than $13 \%, 13 \%$, and $20 \%$, respectively. At every time point during treatment, mean $\mathrm{FEV}_{1}$, mean FVC, and mean $\mathrm{FEF}_{25-75}$ were higher in the azithromycin-treated patients than in the placebo patients. However, the median relative difference in predicted $\mathrm{FEV}_{1}$ between azithromycin and placebo was only $5.4 \%$ ( $>00.05)$. Improvement in $\mathrm{FEV}_{1}$ greater than $13 \%$ was noted in 13 of 41 patients, whereas deterioration of more than 13\% was observed in five $(p=0.059)$. The median relative difference in predicted FVC and $\mathrm{FEF}_{25-75}$ between the two groups was 3.9\% and $11.4 \%$, respectively $(p>0.05)$. The results of this study 
suggest that azithromycin treatment in children and adolescents may exert clinically important beneficial effects on pulmonary function in approximately $33 \%$ of patients but may result in worsening lung function in approximately $10-20 \%$ of patients.

The second study involving patients younger than 18 years was a randomized, controlled study in 185 patients aged 6 years or older with a history of chronic $P$. aeruginosa colonization and a predicted $\mathrm{FEV}_{1}$ of $30 \%$ or more. ${ }^{107}$ Of the 185 patients, 15 (average body weight $<40 \mathrm{~kg}$ ) received azithromycin $250 \mathrm{mg} 3$ times/week, 72 (average body weight $\geq 40 \mathrm{~kg}$ ) azithromycin 500 mg 3 times/week, and 98 placebo. Study exclusion criteria were a history of $B$. cepacia or nontuberculosis mycobacteria within 2 years of screening, active liver disease, therapy with intravenous or oral antibiotics within 14 days of screening, therapy with a corticosteroid $20 \mathrm{mg}$ or more within 30 days of screening, and therapy with inhaled tobramycin, dornase alfa, or highdose ibuprofen begun within 60 days of screening.

Use of dornase alfa and inhaled tobramycin were similar in the treatment and placebo groups. In the azithromycin group (both dosage groups) nine patients were $6-12$ years of age, 35 were 13-18 years, and 43 were older than 18 years. The primary end point, relative change in $\mathrm{FEV}_{1}$, was $6.2 \%$ in favor of azithromycin. This was depicted through a $4.4 \%$ improvement in the azithromycin group and a decline of $1.8 \%$ in the placebo group $(p=0.001)$. The response was observed at day 28 and persisted until the end of treatment.

Four weeks after azithromycin discontinuation, $\mathrm{FEV}_{1}$ returned to nearly baseline percentages, indicating the need for prolonged therapy to maintain beneficial effects. Predicted FVC improved $3.7 \%$ in the azithromycin group but declined $1.3 \%$ in the placebo group ( $\mathrm{p}=0.002)$. The rate of weight gain was higher in the azithromycin-treated patients, who gained an average of $0.7 \mathrm{~kg}$ more than those treated with placebo $(p=0.02)$. Azithromycin treatment resulted in significantly fewer respiratory exacerbations $(p=0.03)$ and was associated with fewer hospitalizations $(p=0.05)$. Based on the cystic fibrosis quality-of-life questionnaire, physical functioning improved $(\mathrm{p}=0.05)$ but not total quality of life $(\mathrm{p}=0.35)$. This study reported improvement in two predictors of mortality in patients with cystic fibrosis-pulmonary function and nutritional status-which suggests that azithromycin may be of benefit in children with this disease.

Clinical experience suggests that azithromycin is better tolerated than other macrolide antibiotics. Two placebo-controlled studies reported that azithromycin treatment produced no adverse effects in children or adults with cystic fibrosis. ${ }^{105}$, 106 In a third study with safety as a primary end point, most adverse events were of mild-tomoderate intensity. ${ }^{107}$ In azithromycin and placebo groups, nausea (33\% vs 16\%), diarrhea ( $23 \%$ vs $8 \%$ ) and wheezing ( $17 \%$ vs $4 \%$ ) occurred more frequently in azithromycin-treated patients $(\mathrm{p} \leq 0.01)$. Increased mobilization of respiratory tract secretions was believed to have caused the increased wheezing.

Staphylococcus aureus colonization often occurs at an early age in children with cystic fibrosis. ${ }^{108}$ An increased risk of selecting macrolide-resistant staphylococcal species after azithromycin therapy has been observed in patients with cystic fibrosis. ${ }^{109}$, 110 Since S. aureus is rarely a significant cystic fibrosis pathogen in adolescents or adults, the clinical implications of this finding are debatable.

Nontuberculosis mycobacteria is a second potential respiratory pathogen in cystic fibrosis. Colonization occurs in approximately 13\% of patients with cystic fibrosis, and prevalence increases with age. ${ }^{111,112}$ Although nontuberculosis mycobacteria does not appear to have short-term adverse effects on lung function in patients with cystic fibrosis, effects on long-term outcome cannot be ruled out. ${ }^{112}$ To minimize the risk for selection of macrolide-resistant strains, physicians are advised to screen for nontuberculosis mycobacteria in patients with cystic fibrosis before the start of azithromycin treatment and then every 6 months. ${ }^{113}$ Azithromycin has not increased the risk of bacterial resistance in controlled studies involving patients with cystic fibrosis treated for up to 6 months. ${ }^{105-107}$

Azithromycin has been implicated in fewer drug-drug interactions than other macrolide antibiotics ${ }^{114}$ but has had a strong inhibitory effect on the actions of dornase alfa in vitro, possibly by binding to human DNA and/or to dornase alfa itself. ${ }^{115}$ The suggested interaction between azithromycin and dornase alfa was observed clinically in one randomized controlled study. ${ }^{106}$ However, a subsequent study reported a benefit in lung function associated with azithromycin therapy even though $75 \%$ of patients in the active treatment group were concomitantly treated with dornase alfa. ${ }^{107}$

Azithromycin appears to be a well-tolerated and clinically efficacious antiinflammatory 
treatment modality for maintenance of lung function in children and adults with cystic fibrosis. ${ }^{105-107}$ Most experience with azithromycin has been with patients older than 13 years with a history of chronic $P$. aeruginosa colonization; it has not been studied in children younger than 6 years. Azithromycin $250 \mathrm{mg} 3$ times/week in patients weighing less than $40 \mathrm{~kg}$ and $500 \mathrm{mg} 3$ times/week in those weighing $40 \mathrm{~kg}$ or more may be recommended in patients aged 6 years or older with chronic P. aeruginosa colonization. Azithromycin may benefit patients without a documented history of $P$. aeruginosa with suspected infection, although supporting literature is lacking.

The beneficial effects of azithromycin in patients with cystic fibrosis are generally observed as early as 1 month after the start of treatment but may be delayed for 4-6 months in some patients. ${ }^{106,107}$ Both caregivers and patients should be informed of this variability in response time. Azithromycin therapy for up to 6 months appears to be safe; nausea, diarrhea, and wheezing are the predominant adverse effects. ${ }^{107}$ Continuing therapy seems necessary to maintain the benefits associated with azithromycin therapy. An evaluation of the safety and efficacy of this agent for treatment periods longer than 6 months is in progress.

\section{Additional Therapies with Possible Antiinflammatory Effects}

\section{Colchicine}

Colchicine is an antiinflammatory agent commonly prescribed for treatment of acute attacks of gout. A single open-label study evaluated the potential benefits of colchicine in patients with cystic fibrosis lung disease. ${ }^{116}$ The study involved eight patients aged 5-28 years (median 13.5 yrs) with end-stage cystic fibrosis lung disease unresponsive to conventional therapy. Treatment with colchicine $1 \mathrm{mg} /$ day for 6-12 months (median $7 \mathrm{mo}$ ) was associated with a subjective improvement in clinical status, a significant decrease in antibiotic requirement, and a potential improvement in pulmonary function.

Among the eight patients studied, baseline median predicted $\mathrm{FEV}_{1}$ and FVC, respectively, were $62 \%$ (range 32-68\%) and 54\% (range 21-63\%). Colchicine treatment was associated with a statistically significant decrease in median days of antibiotic therapy, from 5 days/month to 1.2 days/month $(p<0.05)$. A significant improve- ment in $\mathrm{FEV}_{1}$ and FVC was not observed; however, the predicted $\mathrm{FEV}_{1}$ increased in six of the eight patients treated. Mild diarrhea was reported in two patients, but colchicine treatment was generally well tolerated.

The results of this study are compelling enough to justify a large, randomized trial to further evaluate the role of colchicine in patients with cystic fibrosis lung disease.

\section{Dornase alfa}

Dornase alfa (recombinant human deoxyribonucleic acid I) is a mucolytic agent that improves mucociliary clearance through the hydrolysis of extracellular deoxyribonucleic acid in mucus of the cystic fibrosis airway. ${ }^{117}$ In randomized trials, dornase alfa $2.5 \mathrm{mg} /$ day improved pulmonary function (increase in $\mathrm{FEV}_{1}$ $3-16 \%)$ and decreased the risk of pulmonary exacerbations. ${ }^{118-121}$ The response is variable, and younger patients appear to respond better than older patients. ${ }^{118,121,122}$ Treatment with dornase alfa has been well tolerated for up to 2 years. ${ }^{118-121,}$ 123 Although experience is limited regarding administration of this agent to patients younger than 5 years, it may be given to certain patients deemed to be at significant risk of pulmonary function deterioration and/or respiratory tract infection. ${ }^{117}$ Upper airway irritation, characterized by voice alteration and laryngitis, are the only adverse effects reported more frequently with dornase alfa than placebo. ${ }^{118}$

Airway inflammation may transiently increase after the start of treatment with dornase alfa. ${ }^{124,125}$ However, long-term therapy (3 yrs) appears to mitigate inflammation by preventing the progressive increase in total IL-8 sputum concentrations and free elastase activity that accompanies cystic fibrosis lung disease. ${ }^{126}$ The antiinflammatory mechanism of dornase alfa is unclear. It may modulate inflammation by increasing the clearance of neutrophil and neutrophil-degradation product-rich secretions, or by decreasing the frequency of pulmonary exacerbations, thus limiting neutrophil infiltra-tion and the release of neutrophil-degradation products.

\section{Methotrexate}

Methotrexate is a folic acid antagonist with well-known antiinflammatory properties. Although the antiinflammatory mechanism of methotrexate in the cystic fibrosis lung is unknown, the promotion of adenosine release and/or the inhibition of transmethylation 
reactions may play a role. ${ }^{127}$ In a retrospective study, clinical data were analyzed for five patients with $P$. aeruginosa colonization and advanced cystic fibrosis lung disease (predicted $\mathrm{FEV}_{1}$ $25-65 \%$ at the start of treatment) unresponsive to conventional therapy. ${ }^{128}$ The patients, aged 8.2-19.2 years, received oral methotrexate $10-20$ $\mathrm{mg} / \mathrm{m}^{2}$ once/week. In the year preceding the start of treatment, a median $10.5 \%$ decrease in $\mathrm{FEV}_{1}$ was observed $(p<0.005)$. After 1 year of treatment, $\mathrm{FEV}_{1}$ increased by a median of $9 \%$ (range $2-15 \%, \mathrm{p}<0.05)$. In four of the five patients, IgG levels decreased after initiation of methotrexate. No severe adverse effects were observed.

These data suggest a potential benefit of methotrexate in patients with advanced cystic fibrosis lung disease. However, the retrospective study design and the small number of patients involved precludes firm conclusions regarding the safety or efficacy of methotrexate. Controlled, prospective studies are needed.

\section{Montelukast}

The selective cysteinyl leukotriene receptor antagonist montelukast is indicated for treatment of asthma and for relief of symptoms associated with seasonal allergic rhinitis. ${ }^{129}$ Most patients with cystic fibrosis have insufficient bronchial lability to meet the diagnostic criteria for asthma. ${ }^{130}$ As with asthma, however, patients with cystic fibrosis have increased airway cysteinyl leukotriene levels, which may contribute to airway inflammation. ${ }^{131}$ Montelukast has been studied as a treatment for patients with cystic fibrosis. ${ }^{130,132}$ The pharmacokinetic profile of montelukast does not appear to be different in patients with cystic fibrosis compared with the general population. ${ }^{133}$ The dose and dosing interval used to treat asthma may be extrapolated to cystic fibrosis if similar target concentrations are desired.

Two studies have evaluated the safety and efficacy of montelukast in children and adults with cystic fibrosis. ${ }^{130,132}$ In an open-label, observational study, 11 patients aged $16-44$ years (mean 25.9 yrs) with stable cystic fibrosis (predicted $\mathrm{FEV}_{1}<65 \%$ ) were treated with montelukast $10 \mathrm{mg}$ at bedtime for 2 weeks. ${ }^{130}$ At study conclusion, improvement was observed in exercise tolerance $(\mathrm{p}=0.008)$ and morning peak expiratory flow rate $(\mathrm{p}=0.003)$, but $\mathrm{FEV}_{1}$ remained unchanged. Of interest, the patients who improved the most were those who also had positive Aspergillus serology results.
The second study was a randomized, doubleblind, placebo-controlled crossover trial involving 16 patients (10 boys, 6 girls), aged 6-18 years (median 9.5 yrs), with mild cystic fibrosis lung disease (predicted $\mathrm{FEV}_{1} 70$ 125\%). ${ }^{132}$ Patients were treated with montelukast $5 \mathrm{mg}$ (those aged 6-14 yrs) or $10 \mathrm{mg}$ (those aged $>14$ yrs) once/day for 21 days in a crossover design with a 4-week washout period. Treatment with montelukast was associated with reduced eosinophilic inflammation, which was noted by a decrease in serum eosinophil cationic protein $(\mathrm{p} \leq 0.02)$ and eosinophil count $(\mathrm{p} \leq 0.027)$. However, no significant change was noted in clinical symptom score or lung function parameters $\left(\mathrm{FEV}_{1}, \mathrm{FVC}\right)$.

Montelukast was well tolerated in both studies. ${ }^{130,132}$ Large, multicenter trials with longer observation periods are needed to further evaluate the safety and efficacy of montelukast as an antiinflammatory agent in patients with cystic fibrosis. Montelukast $4 \mathrm{mg}$ for patients aged 5 years or younger, $5 \mathrm{mg}$ for those aged 6-14 years, and $10 \mathrm{mg}$ for those aged 15 years or older may benefit patients with cystic fibrosis who also have an asthmatic or allergic rhinitis component.

\section{Pentoxifylline}

Pentoxifylline, a nonspecific inhibitor of phosphodiesterase, is believed to moderate inflammation by increasing intracellular cyclic adenosine $3^{\prime}, 5^{\prime}$-monophosphate. ${ }^{134}$ Pentoxifylline blocks the inflammatory actions of tumor necrosis factor (TNF)- $\alpha$ and affects cytokine expression in a concentration-dependent manner. ${ }^{135-146}$ Neutrophil function may be mitigated through antagonism of these mediators. ${ }^{135}$, 147-150 Ex vivo, pentoxifylline has blocked the destructive action of stimulated neutrophils in isolated perfused lungs. ${ }^{147}$ Studies have demonstrated the ability of pentoxifylline to suppress neutrophil influx and ameliorate pulmonary damage of primates infected with $P$. aeruginosa ${ }^{148}$ and improve airway patency and responsiveness in healthy volunteers treated with an inhaled endotoxin. ${ }^{151}$ These findings led to the investigation of pentoxifylline in patients with cystic fibrosis.

In a randomized, double-blind, placebocontrolled study, 16 patients with $P$. aeruginosa colonization were treated with pentoxifylline or placebo for 6 months. ${ }^{152}$ Nine patients aged $12-33$ years (mean \pm SD $8.2 \pm 8.0$ yrs) received sustained-release pentoxifylline $400 \mathrm{mg} 4$ 
times/day, mean dose $42.6 \pm 4.2 \mathrm{mg} / \mathrm{kg} /$ day; seven patients aged $12-32$ years (mean \pm SD $20.7 \pm 7.0$ yrs) received placebo.

At study conclusion, mean sputum elastase concentration was significantly higher than at baseline in the placebo group $(p<0.05)$. Concentrations were decreased in two of the nine patients in the treatment group, but were similar to those at baseline in the remaining seven patients. The FVC was improved in four patients receiving pentoxifylline versus none in the placebo group. Mean FVC declined $7.2 \%$ and $0.8 \%$ in the placebo and treatment groups, respectively $(\mathrm{p}=0.33)$. Values for $\mathrm{FEV}_{1}$ and $\mathrm{FEF}_{25-75}$ also were not significantly different between the two groups. Of the seven placebo patients, four had a pulmonary exacerbation requiring hospitalization for antibiotic treatment, whereas only one of the nine pentoxifyllinetreated patients was hospitalized for treatment ( $\mathrm{p}=0.077)$.

This study suggests a potential role for pentoxifylline in patients with cystic fibrosis. Larger, randomized trials need be conducted in both children and adults with cystic fibrosis before treatment with this agent can be recommended. However, even if further studies suggest a benefit, compliance with a 4-times/day regimen would likely be difficult.

\section{Nutritional Supplements}

In patients with cystic fibrosis, the lungs are exposed to extensive oxidative stress, an effect that may result from a decrease in antioxidant defenses. ${ }^{14,15}$ The low plasma levels of antioxidants may result from an increase in turnover or metabolism of these substances. ${ }^{16}$ Supplementation could correct this imbalance and thus possibly attenuate lung inflammation.

\section{$\beta$-Carotene}

Plasma levels of $\beta$-carotene are significantly lower in patients with cystic fibrosis than in healthy controls, and the plasma level of $\beta$ carotene is inversely correlated with IgG levels. ${ }^{16}$, ${ }^{153-161}$ Together, this suggests a possible relationship between $\beta$-carotene deficiency and pulmonary inflammation. ${ }^{16}$ Improving plasma $\beta$-carotene concentrations with supplementation has been associated with improved pulmonary function and a reduced rate of exacerbations. ${ }^{159,160,162}$

Supplementation with $\beta$-carotene $0.5-1.0$ $\mathrm{mg} / \mathrm{kg}$ can correct the deficiency commonly observed in patients with cystic fibrosis. ${ }^{154,155,}$
157-161 Studies have indicated that nearly normal concentrations of $\beta$-carotene were reached 3-4 weeks after the start of therapy and plateaued thereafter. ${ }^{155,}$ 157-159 Treatment with $\beta$-carotene also has reduced malondialdehyde concentrations, a mediator of pulmonary dysfunction. ${ }^{155-161,163}$

Two controlled studies ${ }^{159,} 160$ evaluating the clinical efficacy of $\beta$-carotene supplementation in cystic fibrosis were conducted in a total of 48 patients (mean age $11.7 \mathrm{yrs}^{160}$ and $12.8 \mathrm{yrs}^{159}$ ). In both studies, patients were treated for 12 weeks with $\beta$-carotene $1 \mathrm{mg} / \mathrm{kg}$, to a maximum dosage of $50 \mathrm{mg} /$ day. Pulmonary exacerbations, depicted as the number of days patients were treated with antibiotics, were significantly reduced in both studies ( $\mathrm{p}<0.05)$. In addition, predicted $\mathrm{FEV}_{1}$ - but not predicted $\mathrm{FVC}$-was improved in the first study's younger patients. ${ }^{159}$ This benefit was not statistically significant, but the improvement in pulmonary function was correlated with $\beta$-carotene concentrations. The second study demonstrated no improvement in pulmonary function. ${ }^{160}$ Data assessing the effect of $\beta$-carotene on pulmonary function are conflicting.

Further studies are needed to determine definitively the effect of this supplement on pulmonary function because these two studies were inadequately powered to detect a difference if one existed. Therapy with $\beta$-carotene $0.5-1$ $\mathrm{mg} / \mathrm{kg} /$ day, to a maximum dosage of $50 \mathrm{mg} /$ day, appears to be well tolerated. ${ }^{155,159,160}$

\section{Essential Fatty Acids}

Patients with cystic fibrosis are often deficient in essential fatty acids. This deficiency may result from innate abnormalities in fatty acid metabolism. ${ }^{164-167}$ Plasma omega-3 fatty acid concentrations have correlated with pulmonary function in cystic fibrosis. ${ }^{168}$ These fatty acids inhibit generation of leukotriene $\mathrm{B}_{4}$ by neutrophils and may suppress the production of IL-1 and TNF- $\alpha .^{24}$

A short-term benefit has been observed after intense supplementation with intravenous fatty acids. ${ }^{169}$ However, parenteral therapy does not seem to offer substantial clinical benefit, and addition of routine intravenous therapy may add undue psychological stress to treated patients. ${ }^{169}$, 170 Orally administered omega-3 fatty acids in the form of fish oil may mitigate lung damage in patients with cystic fibrosis. Fish oil contains the omega-3 fatty acids eicosapentaenoic acid and docosahexaenoic acid; both possess antiinflammatory properties. Several studies have demon- 
strated the feasibility of correcting fatty acid deficiency and pancreatic insufficiency through dietary fish oil supplementation in patients with cystic fibrosis. ${ }^{171-174}$ Decreased production of leukotriene $\mathrm{B}_{4}$ in the airways, with a subsequent decrease in exposure of leukotriene $\mathrm{B}_{4}$ to circulating neutrophils, has been suggested by several studies as the mechanism for this potential clinical benefit of fish oil in patients with cystic fibrosis. ${ }^{167,173,175,176}$

Two studies observed that treatment with fish oil was associated with beneficial effects on pulmonary function. ${ }^{167,175}$ The first study, a randomized, double-blind, placebo-controlled trial, involved 16 patients with cystic fibrosis and colonized with P. aeruginosa. ${ }^{175}$ The patients, aged 12-26 years (median 17 yrs), were treated with a 6-week course of fish oil capsules providing $2.7 \mathrm{~g} /$ day of eicosapentaenoic acid. Treatment resulted in a significant reduction in sputum volume $(\mathrm{p}=0.015)$ and an improved Shwachman score $(p=0.034), F V_{1}(p=0.006)$, and vital capacity $(\mathrm{p}=0.011)$ compared with placebo.

The second study involved 30 patients with cystic fibrosis, aged $0.8-24.0$ years (mean 12.4 yrs), with $P$. aeruginosa colonization and pancreatic insufficiency. ${ }^{167}$ These patients were treated with omega-3 fatty acids in the form of fish oil in a mean daily dose containing $1.28 \mathrm{~g}$ of eicosapentaenoic acid and $0.93 \mathrm{~g}$ of docosahexaenoic acid. After 8 months of supplementation, a small improvement was observed in $\mathrm{FEV}_{1}(\mathrm{p}<0.05)$ and in number of days of antibiotic treatment $(\mathrm{p}<0.05)$.

Fish oil is a relatively benign therapy when administered to patients with cystic fibrosis. Gastrointestinal symptoms are the most commonly reported adverse effects; eructation, diarrhea, and steatorrhea often necessitate an increased dosage of pancreatic enzymes. ${ }^{172,173,175}$ Persistence of these gastrointestinal symptoms, or the need for higher dosages of enzymes than recommended, may limit the utility of fish oil therapy in certain patients. Elevations of alanine aminotransferase may also occur with supple-mentation with omega-3 fatty acids. ${ }^{177}$ Liver function tests should be monitored before treatment with fish oil and as indicated during treatment.

\section{Future Directions}

In healthy individuals, the epithelial surface of the lung is protected from the destructive action of neutrophil elastase by two antiproteases: $\alpha_{1^{-}}$ antitrypsin and secretory leukoprotease inhibitor (SLPI). 9, 18, 19 The lower respiratory tract is protected predominantly by $\alpha_{1}$-antitrypsin, whereas SLPI provides the major anti-neutrophil elastase protective screen at the epithelial surface of the upper airways. ${ }^{19,}{ }^{178}$ Although present in normal concentrations, $\alpha_{1}$-antitrypsin and SLPI are overwhelmed by neutrophil elastase in the cystic fibrosis lung at an early age. ${ }^{9,}$ 17-19 Active neutrophil elastase is thus allowed to injure the lung continuously, increasing secretion of mucus; enhancing chemoattraction; stimulating production of chemoattractants, such as IL-8, IL-6, and leukotriene $\mathrm{B}_{4}$; and impairing opsonization and the ability of the host to eliminate bacterial pathogens, such as $P$. aeruginosa. ${ }^{18}$

Pharmacologic replacement of active antiproteases may be a novel therapeutic approach to reduce the neutrophil elastase burden on the respiratory epithelial surface in patients with cystic fibrosis, thus ameliorating inherent inflammatory actions. The potential utility of both SLPI and $\alpha_{1}$-antitrypsin in patients with cystic fibrosis lung disease have been investigated. ${ }^{17,178-186}$

In patients with cystic fibrosis, inhalation of recombinant (r) SLPI $100 \mathrm{mg}$ every 12 hours effectively increases epithelial lining fluid SLPI and decreases epithelial lining fluid neutrophil elastase and IL-8 concentrations. ${ }^{180,181}$ The increase in anti-neutrophil elastase capacity is immediate and coincides with the rise in epithelial lining fluid SLPI concentrations, whereas the decrease in epithelial lining fluid neutrophil elastase concentrations correlates with the reduction in IL- $8 .{ }^{180}$ Hence, suppressing neutrophil elastase, a stimulus for IL-8 production, which decreases neutrophil chemoattraction to the lung and further lessens neutrophil elastase concentrations, may mitigate lung damage. In addition to its effects on neutrophil elastase, rSLPI also raises epithelial lining fluid concentrations of the antioxidant glutathione, which are often lower than normal in patients with cystic fibrosis. ${ }^{182,187}$ The subsequent increase in antioxidant capacity of the epithelial lining fluid is delayed for 24 hours after inhalation. $^{182}$

Treatment with rSLPI 100 mg every 12 hours was administered to 45 adults (mean \pm SD age 27 \pm 2 yrs) with cystic fibrosis for 7 days without adverse effects. ${ }^{180,181}$ Tissue concentrations of rSLPI did not accumulate. ${ }^{181}$ Because the imbalance of protease and oxidant constitutes a major component of inflammation in cystic 
fibrosis lung disease, rSLPI may provide a dual benefit. However, rSLPI does not distribute well to poorly ventilated and highly inflamed areas of the lung. ${ }^{188}$ Therefore, although functional lung tissue may be protected, inhaled rSLPI may be of minimal benefit in patients with severe lung disease. Controlled studies are needed to assess the safety and efficacy of rSLPI for pulmonary function in patients with mild-to-moderate cystic fibrosis lung disease.

The antiprotease $\alpha_{1}$-antitrypsin increases epithelial lining fluid $\alpha_{1}$-antitrypsin concentrations; suppresses active neutrophil elastase, increasing the anti-neutrophil elastase capacity; reduces proteolysis; and reverses the ability of respiratory epithelial lining fluid to interfere with neutrophil killing of $P$. aeruginosa. ${ }^{184,185}$ In contrast to rSLPI, $\alpha_{1}$-antitrypsin does not increase epithelial lining fluid glutathione levels and thus has no direct antioxidant activity.

Inhaled $\alpha_{1}$-antitrypsin distributes to the distal air spaces of the lung. ${ }^{189,} 190$ In a study of 26 patients with cystic fibrosis, $\alpha_{1}$-antitrypsin 100 , 250 , and $350 \mathrm{mg}$ twice/day significantly decreased neutrophil elastase activity. ${ }^{186}$ A trend toward greater elastase inhibition was noted with higher dosages. Treatment has also been associated with reduced proteolysis, but no benefit in lung function has been observed. ${ }^{185}$ Inhaled $\alpha_{1}$-antitrypsin has been well tolerated. ${ }^{186}$ The effect of $\alpha_{1}$-antitrypsin on lung function and progression of lung damage in patients with cystic fibrosis is unknown.

The utility of inhaled recombinant human monocyte and neutrophil elastase inhibitor, the oral antiproteases L-658,758, DMP 777, ICI 200,355 , and chemically modified tetracyclines is under investigation. ${ }^{1,191-196}$ Initial in vitro and animal data are intriguing, and further studies investigating the role of these anti-neutrophil elastase agents are warranted. The host defense of a patient with cystic fibrosis lung disease may be augmented through administration of IL-10. ${ }^{197}$ The use of a recombinant IL-10 preparation is under investigation.

\section{Conclusion}

Inflammation is a major component of the vicious cycle characterizing cystic fibrosis pulmonary disease. If untreated, this inflam-matory process irreversibly damages the airways, leading to bronchiectasis and ultimately respiratory failure. Most morbidity and nearly all mortality in patients with cystic fibrosis are associated with pulmonary disease. Thus, interrupting the cycle of obstruction, infection, and inflammation with antiinflammatory agents may have a positive impact on disease progression.

Investigators have observed that pulmonary inflammation can be mitigated pharmacologically by drugs and supplements that affect the function or migration of neutrophils, modify the activity of proinflammatory and antiinflammatory cytokines and chemokines, antagonize the virulence of bacteria such as $P$. aeruginosa, improve the oxidant-antioxidant and protease-antiprotease imbalance, or possibly directly affect the cystic fibrosis transmembrane conductance regulator gene.

Treatment with oral corticosteroids and ibuprofen is associated with beneficial effects on several disease parameters; however, oral corticosteroid therapy is limited by adverse effects. Children with cystic fibrosis can be treated with ibuprofen, assuming treatment is begun when they are aged 5-13 years and the clinician commits to evaluating patient tolerability and to monitoring plasma concentrations routinely to ensure efficacy and minimize toxicity. Inhaled corticosteroids, though well tolerated, do not appear to affect inflammation of the cystic fibrosis airway to a great extent. The decision to administer inhaled corticosteroids in children with cystic fibrosis should be made on a patient-to-patient basis.

Azithromycin, which has been effective and well tolerated, is the most promising antiinflammatory therapeutic agent for treatment of cystic fibrosis pulmonary disease. Therapy with this agent can be recommended for children aged 6 years or older with $P$. aeruginosa colonization or a suspected history of $P$. aeruginosa colonization.

The most appropriate patient age at which antiinflammatory treatment should be started is a topic of debate. However, because the antiinflammatory therapies are preventive, younger patients would be expected to benefit to a greater extent than those in whom substantial lung damage has already occurred. Therefore, early initiation of antiinflammatory therapy should be recommended. Future studies should be directed toward establishing the safety and efficacy of these therapies in children younger than 5 years.

\section{References}

1. Kennedy MJ. Inflammation and cystic fibrosis pulmonary disease. Pharmacotherapy 2001;21:593-603.

2. Boucher RC. An overview of the pathogenesis of cystic fibrosis lung disease. Adv Drug Deliv Rev 2002;54:1359-71. 
3. Konstan MW, Berger M. Current understanding of the inflammatory process in cystic fibrosis: onset and etiology. Pediatr Pulmonol 1997;24:137-42.

4. Khan TZ, Wagener JS, Bost T, Martinez J, Accurso FJ, Riches DW. Early pulmonary inflammation in infants with cystic fibrosis. Am J Respir Crit Care Med 1995;151:1075-82.

5. Armstrong DS, Grimwood K, Carzino R, Carlin JB, Olinsky A, Phelan PD. Lower respiratory infection and inflammation in infants with newly diagnosed cystic fibrosis. BMJ 1995;310:1571-2.

6. Armstrong DS, Grimwood K, Carlin JB, Carzino R, Olinsky A, Phelan PD. Bronchoalveolar lavage or oropharyngeal cultures to identify lower respiratory pathogens in infants with cystic fibrosis. Pediatr Pulmonol 1996;21:267-75.

7. Armstrong DS, Grimwood K, Carlin JB, et al. Lower airway inflammation in infants and young children with cystic fibrosis. Am J Respir Crit Care Med 1997;156:1197-204.

8. Balough K, McCubbin M, Weinberger M, Smits W, Ahrens R, Fick R. The relationship between infection and inflammation in the early stages of lung disease from cystic fibrosis. Pediatr Pulmonol 1995;20:63-70.

9. Birrer P, McElvaney NG, Rudeberg A, et al. Proteaseantiprotease imbalance in the lungs of children with cystic fibrosis. Am J Respir Crit Care Med 1994;150:207-13.

10. Konstan MW, Hilliard KA, Norvell TM, Berger M. Bronchoalveolar lavage findings in cystic fibrosis patients with stable, clinically mild lung disease suggest ongoing infection and inflammation. Am J Respir Crit Care Med 1994;150: $448-54$.

11. Rosenfeld M, Gibson RL, McNamara S, et al. Early pulmonary infection, inflammation, and clinical outcomes in infants with cystic fibrosis. Pediatr Pulmonol 2001;32: 356-66.

12. Hamutcu R, Woo MS. Advanced cystic fibrosis lung disease in children. Curr Opin Pulm Med 2001;7:448-53

13. Oermann CM, Sockrider MM, Konstan MW. The use of antiinflammatory medications in cystic fibrosis: trends and physician attitudes. Chest 1999;115:1053-8.

14. van der Vliet A, Eiserich JP, Marelich GP, Halliwell B, Cross CE. Oxidative stress in cystic fibrosis: does it occur and does it matter? Adv Pharmacol 1997;38:491-513.

15. Wood LG, Fitzgerald DA, Gibson PG, Cooper DM, Collins CE, Garg ML. Oxidative stress in cystic fibrosis: dietary and metabolic factors. J Am Coll Nutr 2001;20:157-65.

16. Homnick DN, Cox JH, DeLoof MJ, Ringer TV. Carotenoid levels in normal children and in children with cystic fibrosis. J Pediatr 1993;122:703-7.

17. Hansen G, Schuster A, Zubrod C, Wahn V. $\alpha$-1-Proteinase inhibitor abrogates proteolytic and secretagogue activity of cystic fibrosis sputum. Respiration 1995;62:117-24.

18. Allen ED. Opportunities for the use of aerosolized $\alpha-1$ antitrypsin for the treatment of cystic fibrosis. Chest 1996;110(6 suppl):256S-60.

19. Doring G. Serine proteinase inhibitor therapy in $\alpha-1$ antitrypsin inhibitor deficiency and cystic fibrosis. Pediatr Pulmonol 1999;28:363-75.

20. Bonfield TL, Panuska JR, Konstan MW, et al. Inflammatory cytokines in cystic fibrosis lungs. Am J Respir Crit Care Med 1995; 152:2111-18.

21. Bonfield TL, Konstan MW, Berger M. Altered respiratory epithelial cell cytokine production in cystic fibrosis. J Allergy Clin Immunol 1999;104:72-8.

22. Konstan MW, Walenga RW, Hilliard KA, Hilliard JB. Leukotriene $\mathrm{B}_{4}$ markedly elevated in the epithelial lining fluid of patients with cystic fibrosis. Am Rev Respir Dis 1993;148:896-901.

23. Konstan MW, Davis PB. Pharmacological approaches for the discovery and development of new anti-inflammatory agents for the treatment of cystic fibrosis. Adv Drug Deliv Rev 2002;54:1409-23.

24. Konstan MW. Treatment of airway inflammation in cystic fibrosis. Curr Opin Pulm Med 1996;2:452-6.

25. Greally P, Hussain MJ, Vergani D, Price JF. Interleukin-1- $\alpha$, soluble interleukin-2 receptor, and $\operatorname{IgG}$ concentrations in cystic fibrosis treated with prednisolone. Arch Dis Child 1994;71:35-9.

26. Auerbach HS, Williams M, Kirkpatrick JA, Colten HR. Alternate-day prednisone reduces morbidity and improves pulmonary function in cystic fibrosis. Lancet 1985;2:686-8.

27. Eigen H, Rosenstein BJ, FitzSimmons S, Schidlow DV. A multicenter study of alternate-day prednisone therapy in patients with cystic fibrosis: Cystic fibrosis foundation prednisone trial group. J Pediatr 1995;126:515-23.

28. Donati MA, Haver K, Gerson W, Klein M, McLaughlin FJ, Wohl MEB. Long-term alternate day prednisone therapy in cystic fibrosis [abstr]. Pediatr Pulmonol 1990;5(suppl):277.

29. Lai HC, FitzSimmons SC, Allen DB, et al. Risk of persistent growth impairment after alternate-day prednisone treatment in children with cystic fibrosis. N Engl J Med 2000;342: 851-9.

30. Conway SP, Morton AM, Oldroyd B, et al. Osteoporosis and osteopenia in adults and adolescents with cystic fibrosis: prevalence and associated factors. Thorax 2000;55:798-804.

31. Sauty A, Leuenberger PH, Fitting JW. Cushing's syndrome in a patient with cystic fibrosis treated with itraconazole and deflazacort for allergic bronchopulmonary aspergillosis [abstr]. Eur Respir J 1995;19(suppl):441S.

32. Linthoudt H, Van Raemdonck D, Lerut T, Demedts $M$, Verleden $G$. The association of itraconazole and methylprednisolone may give rise to important steroid-related side effects [letter]. J Heart Lung Transplant 1996;15:1165.

33. Allen DB, Bielory L, Derendorf H, et al. Inhaled corticosteroids: past lessons and future issues. J Allergy Clin Immunol 2003;112(3 suppl):S1-40

34. Schiotz PO, Jorgensen M, Flensborg EW, et al. Chronic Pseudomonas aeruginosa lung infection in cystic fibrosis: a longitudinal study of immune complex activity and inflammatory response in sputum sol-phase of cystic fibrosis patients with chronic Pseudomonas aeruginosa lung infections: influence of local steroid treatment. Acta Paediatr Scand $1983 ; 72: 283-7$

35. van Haren EH, Lammers JW, Festen J, Heijerman HG, Groot CA, van Herwaarden CL. The effects of the inhaled corticosteroid budesonide on lung function and bronchial hyperresponsiveness in adult patients with cystic fibrosis. Respir Med 1995;89:209-14.

36. Nikolaizik WH, Schoni MH. Pilot study to assess the effect of inhaled corticosteroids on lung function in patients with cystic fibrosis. J Pediatr 1996;128:271-4.

37. Bisgaard H, Pedersen SS, Nielsen KG, et al. Controlled trial of inhaled budesonide in patients with cystic fibrosis and chronic bronchopulmonary Pseudomonas aeruginosa infection. Am J Respir Crit Care Med 1997;156:1190-6.

38. Balfour-Lynn IM, Klein NJ, Dinwiddie R. Randomised controlled trial of inhaled corticosteroids (fluticasone propionate) in cystic fibrosis. Arch Dis Child 1997;77:124-30.

39. Dauletbaev N, Viel K, Behr J, et al. Effects of short-term inhaled fluticasone on oxidative burst of sputum cells in cystic fibrosis patients. Eur Respir J 1999;14:1150-5.

40. Wojtczak HA, Kerby GS, Wagener JS, et al. Beclomethasone diproprionate reduced airway inflammation without adrenal suppression in young children with cystic fibrosis: a pilot study. Pediatr Pulmonol 2001;32:293-302.

41. Schmidt J, Davidson AGF, Seear M, et al. Is the acquisition of pseudomonads in cystic fibrosis patients increased by use of inhaled corticosteroids? Unexpected results from a double blind placebo controlled study. Pediatr Pulmonol 1997;14(suppl):293-4.

42. Allen DB. Inhaled corticosteroid therapy for asthma in preschool children: growth issues. Pediatrics 2002;109(2 suppl):373-80.

43. Main KM, Skov M, Sillesen IB, et al. Cushing's syndrome due to pharmacological interaction in a cystic fibrosis patient. Acta Paediatr 2002;91:1008-11.

44. Skov M, Main KM, Sillesen IB, Muller J, Koch C, Lanng S. Iatrogenic adrenal insufficiency as a side-effect of combined 
treatment of itraconazole and budesonide. Eur Respir J 2002;20:127-33.

45. Autret-Leca E. A general overview of the use of ibuprofen in paediatrics. Int J Clin Pract 2003;135(suppl):9-12.

46. Konstan MW, Byard PJ, Hoppel CL, Davis PB. Effect of highdose ibuprofen in patients with cystic fibrosis. N Engl J Med 1995;332:848-54

47. North American Cystic Fibrosis Foundation. Ibuprofen: information for cystic fibrosis physicians. Bethesda, MD: Cystic Fibrosis Foundation, 1995.

48. Brown KA, Collins AJ. Action of nonsteroidal, antiinflammatory drugs on human and rat peripheral leucocyte migration in vitro. Ann Rheum Dis 1977;36:239-43

49. Venezio FR, DiVincenzo C, Pearlman F, Phair JP. Effects of the newer nonsteroidal anti-inflammatory agents, ibuprofen, fenoprofen, and sulindac, on neutrophil adherence. J Infect Dis 1985; 152:690-4.

50. Shimanuki T, Nakamura RM, Dizerega GS. Modulation of leukotaxis by ibuprofen: a quantitative determination in vivo. Inflammation 1985;9:285-95.

51. Maderazo EG, Breaux SP, Woronick CL. Inhibition of human polymorphonuclear leukocyte cell responses by ibuprofen. J Pharm Sci 1984;73:1403-6.

52. Flynn PJ, Becker WK, Vercellotti GM, et al. Ibuprofen inhibits granulocyte responses to inflammatory mediators: a proposed mechanism for reduction of experimental myocardial infarct size. Inflammation 1984;8:33-44.

53. Kaplan HB, Edelson HS, Korchak HM, Given WP, Abramson S, Weissmann G. Effects of non-steroidal anti-inflammatory agents on human neutrophil functions in vitro and in vivo. Biochem Pharmacol 1984:33:371-8.

54. Higgs GA, Eakins KE, Mugridge KG, Moncada S, Vane JR. The effects of non-steroid anti-inflammatory drugs on leukocyte migration in carrageenin-induced inflammation. Eur J Pharmacol 1980;66:81-6.

55. Sordelli DO, Cerquetti MC, el-Tawil G, Ramwell PW, Hooke AM, Bellanti JA. Ibuprofen modifies the inflammatory response of the murine lung to Pseudomonas aeruginosa. Eur J Respir Dis 1985;67:118-27.

56. Rinaldo JE, Dauber JH. Effect of methylprednisolone and of ibuprofen, a nonsteroidal antiinflammatory agent, on bronchoalveolar inflammation following endotoxemia. Circ Shock 1985;16:195-203.

57. Rinaldo JE, Pennock B. Effects of ibuprofen on endotoxininduced alveolitis: biphasic dose response and dissociation between inflammation and hypoxemia. Am J Med Sci 1986;291:29-38.

58. Konstan MW, Hilliard KA, Davis PB. Effect of ibuprofen on neutrophil $(\mathrm{PMN})$ delivery to mucosal surfaces. Pediatr Pulmonol 1989; 7(suppl 4):152-3.

59. Konstan MW, Vargo KM, Davis PB. Ibuprofen attenuates the inflammatory response to Pseudomonas aeruginosa in a rat model of chronic pulmonary infection: implications for antiinflammatory therapy in cystic fibrosis. Am Rev Respir Dis 1990;141:186-92.

60. Konstan MW, Krenicky JE, Finney MR, et al. Effect of ibuprofen on neutrophil migration in vivo in cystic fibrosis and healthy subjects. J Pharmacol Exp Ther 2003;306: 1086-91.

61. Konstan MW, Hoppel CL, Chai BL, Davis PB. Ibuprofen in children with cystic fibrosis: pharmacokinetics and adverse effects. J Pediatr 1991;118:956-64.

62. Arranz I, Martin-Suarez A, Lanao JM, et al. Population pharmacokinetics of high dose ibuprofen in cystic fibrosis. Arch Dis Child 2003;88:1128-30.

63. Murry DJ, Oermann CM, Ou CN, Rognerud C, Seilheimer DK, Sockrider MM. Pharmacokinetics of ibuprofen in patients with cystic fibrosis. Pharmacotherapy 1999;19: 340-5.

64. Rifai N, Sakamoto M, Law T, Galpchian V, Harris N, Colin AA. Use of a rapid HPLC assay for determination of pharmacokinetic parameters of ibuprofen in patients with cystic fibrosis. Clin Chem 1996;42:1812-16.
65. Scott CS, Retsch-Bogart GZ, Kustra RP, Graham KM, Glasscock BJ, Smith PC. The pharmacokinetics of ibuprofen suspension, chewable tablets, and tablets in children with cystic fibrosis. J Pediatr 1999;134:58-63.

66. Beringer P, Aminimanizani A, Synold T, Scott C. Development of population pharmacokinetic models and optimal sampling times for ibuprofen tablet and suspension formulations in children with cystic fibrosis. Ther Drug Monit 2002;24:315-21.

67. Lesko SM, Mitchell AA. An assessment of the safety of pediatric ibuprofen: a practitioner-based randomized clinical trial. JAMA 1995;273:929-33.

68. Garcia Rodriguez LA, Jick H. Risk of upper gastrointestinal bleeding and perforation associated with individual nonsteroidal anti-inflammatory drugs. Lancet 1994;343:769-72.

69. Konstan MW, FitzSimmons SC. Clinical use of ibuprofen for cystic fibrosis (CF) lung disease: data from the $1996 \mathrm{CF}$ foundation national patient registry [abstr]. Pediatr Pulmonol 1997;14(suppl):322.

70. Bell EA, Grothe R, Zivkovich V, Foote JM, Wellendorf J. Pyloric channel stricture secondary to high-dose ibuprofen therapy in a patient with cystic fibrosis. Ann Pharmacother 1999;33:693-6.

71. Kovesi TA, Swartz R, MacDonald N. Transient renal failure due to simultaneous ibuprofen and aminoglycoside therapy in children with cystic fibrosis. N Engl J Med 1998;338:65-6.

72. Scott CS, Retsch-Bogart GZ, Henry MM. Renal failure and vestibular toxicity in an adolescent with cystic fibrosis receiving gentamicin and standard-dose ibuprofen. Pediatr Pulmonol 2001;31:314-16.

73. Corey M, Farewell V. Determinants of mortality from cystic fibrosis in Canada, 1970-1989. Am J Epidemiol 1996;143:1007-17.

74. Silverstein FE, Faich G, Goldstein JL, et al. Gastrointestinal toxicity with celecoxib vs nonsteroidal anti-inflammatory drugs for osteoarthritis and rheumatoid arthritis: the CLASS study: a randomized controlled trial: celecoxib long-term arthritis safety study. JAMA 2000;284:1247-55.

75. Day R, Morrison B, Luza A, et al. A randomized trial of the efficacy and tolerability of the COX-2 inhibitor rofecoxib vs ibuprofen in patients with osteoarthritis. Arch Intern Med 2000;160:1781-7.

76. Sikes DH, Agrawal NM, Zhao WW, Kent JD, Recker DP, Verburg KM. Incidence of gastroduodenal ulcers associated with valdecoxib compared with that of ibuprofen and diclofenac in patients with osteoarthritis. Eur J Gastroenterol Hepatol 2002;14:1101-11.

77. Pfizer Inc. Zithromax (azithromycin) prescribing information. New York; 2003

78. Schoni MH. Macrolide antibiotic therapy in patients with cystic fibrosis. Swiss Med Wkly 2003;133:297-301.

79. Hoiby N. Diffuse panbronchiolitis and cystic fibrosis: east meets west. Thorax 1994;49:531-2.

80. Koyama H, Geddes DM. Erythromycin and diffuse panbronchiolitis. Thorax 1997;52:915-18.

81. Gaylor AS, Reilly JC. Therapy with macrolides in patients with cystic fibrosis. Pharmacotherapy 2002;22:227-39.

82. Culic O, Erakovic V, Cepelak I, et al. Azithromycin modulates neutrophil function and circulating inflammatory mediators in healthy human subjects. Eur J Pharmacol 2002;450:277-89.

83. Ianaro A, Ialenti A, Maffia P, et al. Anti-inflammatory activity of macrolide antibiotics. J Pharmacol Exp Ther 2000;292: 156-63.

84. Wenisch C, Parschalk B, Zedtwitz-Liebenstein K, Weihs A, el Menyawi I, Graninger W. Effect of single oral dose of azithromycin, clarithromycin, and roxithromycin on polymorphonuclear leukocyte function assessed ex vivo by flow cytometry. Antimicrob Agents Chemother 1996;40:2039-42.

85. Levert H, Gressier B, Moutard I, et al. Azithromycin impact on neutrophil oxidative metabolism depends on exposure time. Inflammation 1998;22:191-201.

86. Khan AA, Slifer TR, Araujo FG, Remington JS. Effect of clarithromycin and azithromycin on production of cytokines 
by human monocytes. Int J Antimicrob Agents 1999;11: 121-32.

87. Bell SC, McCormack JG, Yang IA, et al. Azithromycin reduces TNF- $\alpha$ release from lipopolysaccharide stimulated mononuclear cells in cystic fibrosis [abstr]. Pediatr Pulmonol 2000;30(suppl 20):261.

88. Tai S, Sudo E, Sun F, et al. Effect of azithromycin on sputum rheology in cystic fibrosis patients [abstr]. Pediatr Pulmonol 1999;28(suppl 19):264.

89. Saiman L, Chen Y, Gabriel PS, Knirsch C. Synergistic activities of macrolide antibiotics against Pseudomonas aeruginosa, Burkholderia cepacia, Stenotrophomonas maltophilia, and Alcaligenes xylosoxidans isolated from patients with cystic fibrosis. Antimicrob Agents Chemother 2002;46:1105-7.

90. Baumann U, Fischer JJ, Gudowius P, et al. Buccal adherence of Pseudomonas aeruginosa in patients with cystic fibrosis under long-term therapy with azithromycin. Infection 2001;29:7-11.

91. Mizukane R, Hirakata Y, Kaku M, et al. Comparative in vitro exoenzyme-suppressing activities of azithromycin and other macrolide antibiotics against Pseudomonas aeruginosa. Antimicrob Agents Chemother 1994;38:528-33.

92. Molinari G, Guzman CA, Pesce A, Schito GC. Inhibition of Pseudomonas aeruginosa virulence factors by subinhibitory concentrations of azithromycin and other macrolide antibiotics. J Antimicrob Chemother 1993;31:681-8.

93. Kobayashi $\mathrm{H}$. Biofilm disease: its clinical manifestation and therapeutic possibilities of macrolides. Am J Med 1995; 99(suppl 6A):26S-30.

94. Ichimiya T, Takeoka K, Hiramatsu K, Hirai K, Yamasaki T, Nasu M. The influence of azithromycin on the biofilm formation of Pseudomonas aeruginosa in vitro. Chemotherapy 1996;42:186-91.

95. Takeoka K, Ichimiya T, Yamasaki T, Nasu M. The in vitro effect of macrolides on the interaction of human polymorphonuclear leukocytes with Pseudomonas aeruginosa in biofilm. Chemotherapy 1998;44:190-7.

96. Tateda K, Ishii Y, Hirakata Y, Matsumoto T, Ohno A, Yamaguchi K. Profiles of outer membrane proteins and lipopolysaccharide of Pseudomonas aeruginosa grown in the presence of sub-MICs of macrolide antibiotics and their relation to enhanced serum sensitivity. J Antimicrob Chemother 1994;34:931-42.

97. Tateda K, Ishii Y, Matsumoto T, et al. Direct evidence for antipseudomonal activity of macrolides: exposure-dependent bactericidal activity and inhibition of protein synthesis by erythromycin, clarithromycin, and azithromycin. Antimicrob Agents Chemother 1996;40:2271-5.

98. Pradal U, Delmarco A, Cipolli M, Cazzola G. Chloride transport may be restored by long-term azithromycin treatment in patients with cystic fibrosis [abstr]. Pediatr Pulmonol 2000;30(suppl 20):280-1.

99. Altschuler EL. Azithromycin, the multidrug-resistant protein, and cystic fibrosis [letter]. Lancet 1998;351:1286.

100. Pukhalsky AL, Kapranov NI, Kalashnikova EA, et al. Inflammatory markers in cystic fibrosis patients with lung Pseudomonas aeruginosa infection. Mediators Inflamm 1999;8:159-67.

101. Ordonez CL, Stulbarg M, Grundland H, Liu JT, Boushey HA. Effect of clarithromycin on airway obstruction and inflammatory markers in induced sputum in cystic fibrosis: a pilot study. Pediatr Pulmonol 2001;32:29-37.

102. Jaffe A, Francis J, Rosenthal M, Bush A. Long-term azithromycin may improve lung function in children with cystic fibrosis [letter]. Lancet 1998;351:420.

103. Pirzada OM, Taylor CJ. Long term macrolide antibiotics improve pulmonary function in cystic fibrosis [abstr]. Pediatr Pulmonol 1999;28(suppl 19):263.

104. Anstead MI, Kuhn RJ, Halsey S, Kangra JF. Prolonged beneficial effect of chronic azithromycin therapy on lung function in cystic fibrosis [abstr]. Pediatr Pulmonol 2000;30(suppl 20):244.
105. Wolter J, Seeney S, Bell S, Bowler S, Masel P, McCormack J. Effect of long term treatment with azithromycin on disease parameters in cystic fibrosis: a randomised trial. Thorax 2002;57:212-16.

106. Equi A, Balfour-Lynn IM, Bush A, Rosenthal M. Long term azithromycin in children with cystic fibrosis: a randomised, placebo-controlled crossover trial. Lancet 2002;360:978-84.

107. Saiman L, Marshall BC, Mayer-Hamblett N, et al. Azithromycin in patients with cystic fibrosis chronically infected with Pseudomonas aeruginosa: a randomized controlled trial. JAMA 2003;290:1749-56.

108. Kahl BC, Duebbers A, Lubritz G, et al. Population dynamics of persistent Staphylococcus aureus isolated from the airways of cystic fibrosis patients during a 6-year prospective study. J Clin Microbiol 2003;41:4424-7.

109. Prunier AL, Malbruny B, Tande D, Picard B, Leclercq R. Clinical isolates of Staphylococcus aureus with ribosomal mutations conferring resistance to macrolides. Antimicrob Agents Chemother 2002;46:3054-6.

110. Prunier AL, Malbruny B, Laurans M, Brouard J, Duhamel JF, Leclercq R. High rate of macrolide resistance in Staphylococcus aureus strains from patients with cystic fibrosis reveals high proportions of hypermutable strains. J Infect Dis 2003;187:1709-16

111. Olivier KN, Weber DJ, Wallace RJ Jr, et al. Nontuberculous mycobacteria in cystic fibrosis study group: nontuberculous mycobacteria. I: multicenter prevalence study in cystic fibrosis. Am J Respir Crit Care Med 2003;167:828-34.

112. Olivier KN, Weber DJ, Lee JH, et al. Nontuberculous mycobacteria in cystic fibrosis study group: nontuberculous mycobacteria. II: nested-cohort study of impact on cystic fibrosis lung disease. Am J Respir Crit Care Med 2003; $167: 835-40$.

113. Whittier S, Hopfer RL, Knowles MR, Gilligan PH. Improved recovery of mycobacteria from respiratory secretions of patients with cystic fibrosis. J Clin Microbiol 1993;31:861-4.

114. Pai MP, Graci DM, Amsden GW. Macrolide drug interactions: an update. Ann Pharmacother 2000;34:495-513.

115. Ripoll L, Reinert P, Pepin LF, Lagrange PH. Interaction of macrolides with alfa dornase during DNA hydrolysis. J Antimicrob Chemother 1996;37:987-91.

116. Sermet-Gaudelus I, Stoven V, Annereau JP, et al. Interest of colchicine for the treatment of cystic fibrosis patients: preliminary report. Mediators Inflamm 1999;8:13-15.

117. Genetech, Inc. Pulmozyme (dornase alfa) prescribing information. South San Francisco, CA; 2001.

118. Fuchs HJ, Borowitz DS, Christiansen DH, et al. Effect of aerosolized recombinant human DNase on exacerbations of respiratory symptoms and on pulmonary function in patients with cystic fibrosis: the Pulmozyme study group. N Engl J Med 1994:331:637-42.

119. McCoy K, Hamilton S, Johnson C. Effects of 12-week administration of dornase alfa in patients with advanced cystic fibrosis lung disease: Pulmozyme study group. Chest 1996;110:889-95.

120. Quan JM, Tiddens HA, Sy JP, McKenzie SG, et al. Pulmozyme early intervention trial study group: a two-year randomized, placebo-controlled trial of dornase alfa in young patients with cystic fibrosis with mild lung function abnormalities. J Pediatr 2001;139:813-20.

121. Suri R, Metcalfe C, Lees B, et al. Comparison of hypertonic saline and alternate-day or daily recombinant human deoxyribonuclease in children with cystic fibrosis: a randomized trial. Lancet 2001;358:1316-21.

122. Hodson ME, McKenzie S, Harms HK, et al. Dornase alfa in the treatment of cystic fibrosis in Europe: a report from the epidemiologic registry of cystic fibrosis. Pediatr Pulmonol 2003;36:427-32.

123. Shah PL, Scott SF, Geddes DM, Hodson ME. Two years experience with recombinant human DNase I in the treatment of pulmonary disease in cystic fibrosis. Respir Med 1995;89:499-502.

124. Shah PL, Scott SF, Knight RA, Hodson ME. The effects of 
recombinant human DNase on neutrophil elastase activity and interleukin-8 levels in the sputum of patients with cystic fibrosis. Eur Respir J 1996;9:531-4.

125. Perks B, Shute JK. DNA and actin bind and inhibit interleukin-8 function in cystic fibrosis sputa: in vitro effects of mucolytics. Am J Respir Crit Care Med 2000;162:1767-72.

126. Paul K, Rietschel E, Ballmann M, et al. Effect of treatment with dornase alfa on airway inflammation in patients with cystic fibrosis. Am J Respir Crit Care Med 2004;169:719-25.

127. Cronstein BN. The mechanism of action of methotrexate. Rheum Dis Clin North Am 1997;23:739-55.

128. Ballmann M, Junge S, von der Hardt $\mathbf{H}$. Low-dose methotrexate for advanced pulmonary disease in patients with cystic fibrosis. Respir Med 2003;97:498-500

129. Merck \& Co, Inc. Singulair (montelukast) prescribing information. Whitehouse Station, NJ; 2003.

130. Morice AH, Kastelik JA, Aziz I. Montelukast sodium in cystic fibrosis. Thorax 2001;56:244-5.

131. Spencer DA, Sampson AP, Green CP, Costello JF, Piper PJ, Price JF. Sputum cysteinyl-leukotriene levels correlate with the severity of pulmonary disease in children with cystic fibrosis. Pediatr Pulmonol 1992;12:90-4.

132. Schmitt-Grohe S, Eickmeier O, Schubert R, Bez C, Zielen S Anti-inflammatory effects of montelukast in mild cystic fibrosis. Ann Allergy Asthma Immunol 2002;89:599-605.

133. Graff GR, Weber A, Wessler-Starman D, Smith AL. Montelukast pharmacokinetics in cystic fibrosis. J Pediatr 2003;142:53-6.

134. Torphy TJ, Undem BJ. Phosphodiesterase inhibitors: new opportunities for the treatment of asthma. Thorax 1991;46: 512-23.

135. Sullivan GW, Carper HT, Novick WJ Jr, Mandell GL. Inhibition of the inflammatory action of interleukin-1 and tumor necrosis factor $(\alpha)$ on neutrophil function by pentoxifylline. Infect Immun 1988;56:1722-9.

136. Doherty GM, Jensen JC, Alexander HR, Buresh CM, Norton JA. Pentoxifylline suppression of tumor necrosis factor gene transcription. Surgery 1991;110:192-8

137. Neuner P, Klosner G, Schauer E, et al. Pentoxifylline in vivo down-regulates the release of IL-1- $\beta$, IL-6, IL-8 and tumour necrosis factor- $\alpha$ by human peripheral blood mononuclear cells. Immunology 1994;83:262-7.

138. Bienvenu J, Doche C, Gutowski MC, Lenoble M, Lepape A, Perdrix JP. Production of proinflammatory cytokines and cytokines involved in the TH1/TH2 balance is modulated by pentoxifylline. J Cardiovasc Pharmacol 1995;25(suppl 2):S80-4.

139. Staudinger T, Presterl E, Graninger W, et al. Influence of pentoxifylline on cytokine levels and inflammatory parameters in septic shock. Intensive Care Med 1996;22:888-93.

140. D'Hellencourt CL, Diaw L, Cornillet P, Guenounou M. Differential regulation of TNF- $\alpha$, IL-1- $\beta$, IL-6, IL-8, TNF- $\beta$, and IL- 10 by pentoxifylline. Int J Immunopharmacol 1996;18:739-48.

141. Moller DR, Wysocka M, Greenlee BM, et al. Inhibition of human interleukin-12 production by pentoxifylline. Immunology 1997;91:197-203.

142. Marques LJ, Zheng L, Poulakis N, Guzman J, Costabel U. Pentoxifylline inhibits TNF- $\alpha$ production from human alveolar macrophages. Am J Respir Crit Care Med 1999; 159:508-11.

143. Poulakis N, Androutsos G, Kazi D, et al. The differential effect of pentoxifylline on cytokine production by alveolar macrophages and its clinical implications. Respir Med 1999;93:52-7.

144. Tong Z, Chen B, Dai H, Bauer PC, Guzman J, Costabel U. Extrinsic allergic alveolitis: inhibitory effects of pentoxifylline on cytokine production by alveolar macrophages. Ann Allergy Asthma Immunol 2004;92:234-9.

145. Benbernou N, Esnault S, Potron G, Guenounou M. Regulatory effects of pentoxifylline on T-helper cell-derived cytokine production in human blood cells. J Cardiovasc Pharmacol 1995;25(suppl 2):S75-9.
146. Boldt J, Brosch C, Lehmann A, Haisch G, Lang J, Isgro F Prophylactic use of pentoxifylline on inflammation in elderly cardiac surgery patients. Ann Thorac Surg 2001;71:1524-9.

147. McDonald RJ. Pentoxifylline reduces injury to isolated lungs perfused with human neutrophils. Am Rev Resp Dis 1991 144:1347-50.

148. Cheung AT, Moss RB, Leong AB, Novick WJ Jr. Chronic Pseudomonas aeruginosa endobronchitis in rhesus monkeys: I: effect of pentoxifylline on neutrophil influx. J Med Primatol 1992;21:357-62.

149. Seiffge D, Bissinger T, Kremer E, Laux V, Schleyerbach R. Inhibitory effects of pentoxifylline on LPS-induced leukocyte adhesion and macromolecular extravasation in the microcirculation. Inflam Res 1995;44:281-6.

150. Ehrhart I, McCloud L, Creamer KM, Ocasio H. Pentoxifylline markedly reduces pulmonary neutrophil sequestration [abstr]. Chest 1999;116(1 suppl):34S.

151. Rolla G, Bucca C, Brussino L, Dutto L, Colagrande P, Polizzi S. Pentoxifylline attenuates LPS-induced bronchial hyperresponsiveness but not the increase in exhaled nitric oxide. Clin Exp Allergy 1997;27:96-103.

152. Aronoff SC, Quinn FJ Jr, Carpenter LS, Novick WJ Jr. Effects of pentoxifylline on sputum neutrophil elastase and pulmonary function in patients with cystic fibrosis: preliminary observations. J Pediatr 1994;125:992-7.

153. Benabdeslam H, Abidi H, Garcia I, Bellon G, Gilly R, Revol A. Lipid peroxidation and antioxidant defenses in cystic fibrosis patients. Clin Chem Lab Med 1999;37:511-16.

154. Winklhofer-Roob BM, Puhl H, Khoschsorur G, van't Hof MA, Esterbauer H, Shmerling DH. Enhanced resistance to oxidation of low density lipoproteins and decreased lipid peroxide formation during $\beta$-carotene supplementation in cystic fibrosis. Free Radic Biol Med 1995;18:849-59.

155. Winklhofer-Roob BM, van't Hof MA, Shmerling DH. Response to oral $\beta$-carotene supplementation in patients with cystic fibrosis: a 16-month follow-up study. Acta Paediatr 1995;84:1132-6

156. Lepage G, Champagne J, Ronco N, et al. Supplementation with carotenoids corrects increased lipid peroxidation in children with cystic fibrosis. Am J Clin Nutr 1996;64:87-93.

157. Winklhofer-Roob BM, Schlegel-Haueter SE, Khoschsorur G, van't Hof MA, Suter S, Shmerling DH. Neutrophil elastase/ $\alpha$ 1-proteinase inhibitor complex levels decrease in plasma of cystic fibrosis patients during long-term oral $\beta$-carotene supplementation. Pediatr Res 1996;40:130-4.

158. Rust P, Eichler I, Renner S, Elmadfa I. Effects of long term oral $\beta$-carotene supplementation on lipid peroxidation in patients with cystic fibrosis. Int J Vitam Nutr Res 1998;68: 83-7.

159. Rust P, Eichler I, Renner S, Elmadfa I. Long-term oral $\beta$ carotene supplementation in patients with cystic fibrosis: effects on antioxidative status and pulmonary function. Ann Nutr Metab 2000;44:30-7.

160. Renner S, Rath R, Rust P, et al. Effects of $\beta$-carotene supplementation for six months on clinical and laboratory parameters in patients with cystic fibrosis. Thorax 2001;56: 48-52.

161. Cobanoglu N, Ozcelik U, Gocmen A, Kiper N, Dogru D. Antioxidant effect of $\beta$-carotene in cystic fibrosis and bronchiectasis: clinical and laboratory parameters of a pilot study. Acta Paediatr 2002;91:793-8.

162. Wood LG, Fitzgerald DA, Lee AK, Garg ML. Improved antioxidant and fatty acid status of patients with cystic fibrosis after antioxidant supplementation is linked to improved lung function. Am J Clin Nutr 2003;77:150-9.

163. Brown RK, Wyatt H, Price JF, Kelly FJ. Pulmonary dysfunction in cystic fibrosis is associated with oxidative stress. Eur Respir J 1996;9:334-9.

164. Roulet M, Frascarolo P, Rappaz I, Pilet M. Essential fatty acid deficiency in well nourished young cystic fibrosis patients. Eur J Pediatr 1997;156:952-6.

165. Freedman SD, Shea JC, Blanco PG, Alvarez JG. Fatty acids in cystic fibrosis. Curr Opin Pulm Med 2000;6:530-2. 
166. Strandvik B, Gronowitz E, Enlund F, Martinsson T, Wahlstrom J. Essential fatty acid deficiency in relation to genotype in patients with cystic fibrosis. J Pediatr 2001; 139:650-5.

167. De Vizia B, Raia V, Spano C, Pavlidis C, Coruzzo A, Alessio M. Effect of an 8-month treatment with omega-3 fatty acids (eicosapentaenoic and docosahexaenoic) in patients with cystic fibrosis. J Parenter Enteral Nutr 2003;27:52-7.

168. Gibson RA, Teubner JK, Haines K, Cooper DM, Davidson GP. Relationships between pulmonary function and plasma fatty acid levels in cystic fibrosis patients. J Pediatr Gastroenterol Nutr 1986;5:408-15.

169. Kusoffsky E, Strandvik B, Troell S. Prospective study of fatty acid supplementation over 3 years in patients with cystic fibrosis. J Pediatr Gastroenterol Nutr 1983;2:434-8.

170. Katz DP, Manner T, Furst P, Askanazi J. The use of an intravenous fish oil emulsion enriched with omega-3 fatty acids in patients with cystic fibrosis. Nutrition 1996;12: 334-9.

171. Christophe A, Robberecht E, De Baets F, Franckx H. Increase of long chain omega-3 fatty acids in the major serum lipid classes of patients with cystic fibrosis. Ann Nutr Metab 1992:36:304-12.

172. Henderson WR Jr, Astley SJ, McCready MM, et al. Oral absorption of omega-3 fatty acids in patients with cystic fibrosis who have pancreatic insufficiency and in healthy control subjects. J Pediatr 1994;124:400-8.

173. Kurlandsky LE, Bennink MR, Webb PM, Ulrich PJ, Baer LJ. The absorption and effect of dietary supplementation with omega-3 fatty acids on serum leukotriene $B_{4}$ in patients with cystic fibrosis. Pediatr Pulmonol 1994;18:211-17.

174. Clandinin MT, Zuberbuhler P, Brown NE, Kielo ES, Goh YK. Fatty acid pool size in plasma lipoprotein fractions of cystic fibrosis patients. Am J Clin Nutr 1995;62:1268-75.

175. Lawrence R, Sorrell T. Eicosapentaenoic acid in cystic fibrosis: evidence of a pathogenetic role for leukotriene $B_{4}$. Lancet 1993;342:465-9.

176. Lawrence RH, Sorrell TC. Eicosapentaenoic acid modulates neutrophil leukotriene $B_{4}$ receptor expression in cystic fibrosis. Clin Exper Immunol 1994;98:12-16.

177. Henderson WR Jr, Astley SJ, Ramsey BW. Liver function in patients with cystic fibrosis ingesting fish oil. J Pediatr 1994;125:504-5.

178. Vogelmeier C, Biedermann T, Maier K, et al. Comparative loss of activity of recombinant secretory leukoprotease inhibitor and $\alpha$-1-protease inhibitor caused by different forms of oxidative stress. Eur Respir J 1997;10:2114-19.

179. Gast A, Anderson W, Probst A, et al. Pharmacokinetics and distribution of recombinant secretory leukocyte proteinase inhibitor in rats. Am Rev Respir Dis 1990;141:889-94.

180. McElvaney NG, Nakamura H, Birrer P, et al. Modulation of airway inflammation in cystic fibrosis: in vivo suppression of interleukin-8 levels on the respiratory epithelial surface by aerosolization of recombinant secretory leukoprotease inhibitor. J Clin Invest 1992;90:1296-301.

181. McElvaney NG, Doujaiji B, Moan MJ, Burnham MR, Wu MC, Crystal RG. Pharmacokinetics of recombinant secretory leukoprotease inhibitor aerosolized to normals and individuals with cystic fibrosis. Am Rev Respir Dis 1993;148: $1056-60$
182. Gillissen A, Birrer P, McElvaney NG, et al. Recombinant secretory leukoprotease inhibitor augments glutathione levels in lung epithelial lining fluid. J Appl Physiol 1993;75:825-32.

183. Schuster A, Hansen G, Zubrod-Eichert C, Wahn V. Effects of native and oxidation-resistant secretory leukoprotease inhibitor on cystic fibrosis sputum: inhibition of neutrophil elastase activity and of sputum-induced secretion from porcine tracheal submucosal glands. Pediatr Res 1996;40: $732-7$.

184. McElvaney NG, Hubbard RC, Birrer P, et al. Aerosol $\alpha-1$ antitrypsin treatment for cystic fibrosis. Lancet 1991;337: 392-4.

185. Griese M, von Bredow C, Birrer P. Reduced proteolysis of surfactant protein A and changes of the bronchoalveolar lavage fluid proteome by inhaled $\alpha$-1-protease inhibitor in cystic fibrosis. Electrophoresis 2001;22:165-71.

186. Berger M, Konstan M, Hilliard J. Aerosolized Prolastin ( $\alpha-1$ protease inhibitor) in CF [abstr]. Pediatr Pulmonol 1995;20:421.

187. Roum JH, Buhl R, McElvaney NG, Borok Z, Crystal RG. Systemic deficiency of glutathione in cystic fibrosis. J Appl Physiol 1993;75:2419-24.

188. Stolk J, Camps J, Feitsman HIJ, Dijkman JH, Pauwels EKJ. Pulmonary deposition and disappearance of aerosolised secretory leucocyte protease inhibitor. Thorax 1995;50: 645-50.

189. Smith RM, Spragg RG. Production and administration to dogs of aerosols of $\alpha$-1-proteinase inhibitor. Am J Med 1988;84:48-51.

190. Smith RM, Traber LD, Traber DL, Spragg RG. Pulmonary deposition and clearance of aerosolized $\alpha-1$-proteinase inhibitor administered to dogs and to sheep. J Clin Invest 1989;84:1145-54.

191. Rees DD, Rogers RA, Cooley J, Mandle RJ, Kenney DM, Remold-O'Donnell E. Recombinant human monocyte/ neutrophil elastase inhibitor protects rat lungs against injury from cystic fibrosis airway secretions. Am J Respir Cell Mol Biol 1999;20:69-78.

192. Rees DD, Brain JD, Wohl ME, Humes JL, Mumford RA. Inhibition of neutrophil elastase in CF sputum by L-658,758. J Pharmacol Exper Ther 1997;283:1201-6.

193. Vender RL, Burcham DL, Quon CY. DMP 777: a synthetic human neutrophil elastase inhibitor as therapy for cystic fibrosis. Pediatr Pulmonol 1998;26(suppl 17):136-7.

194. Quon CY, Chan LL, Burcham DL, Vender RL. Pharmacokinetics and pharmacodynamics of DMP 777, an inhibitor of human neutrophil elastase, in adult cystic fibrosis patients [abstr]. Pediatr Pulmonol 2000;S20:250.

195. Williams JC, Falcone RC, Knee C, et al. Biologic characterization of ICI 200,880 and ICI 200,355, novel inhibitors of human neutrophil elastase. Am Rev Respir Dis 1991;144: 875-83.

196. Abrahamson B, Belucci W, Roemer EJ, Ren CL, Simon SR. Inhibition of matrix metalloproteinase-9 (MMP-9) and neutrophil elastase (NE) by chemically modified tetracyclines (CMTs) [abstr]. Pediatr Pulmonol 1999;S19:317.

197. Chmiel JF, Konstan MW, Knesebeck JE, et al. IL-10 attenuates excessive inflammation in chronic Pseudomonas infection in mice. Am J Respir Crit Care Med 1999;160: 2040-7. 